\title{
The Relationship Between Academic Fiction and Academic Life
}

\subsection{INTRODUCTION}

This chapter explores the ways in which fiction about universities can contribute to an articulation of the value of the humanities. In Imagining the Academy: Higher Education and Popular Culture Susan Edgerton makes an explicit argument for the prolonged interrogation of fictional representation in debates concerning economic pressures and value within contemporary higher education: "in an institution that is increasingly operating as a corporation, we are continually striving to 'please the customer,' as if we know what the customer wants" $(2005,2)$. For Edgerton, media representation opens up a space between universities and popular opinion by revealing the desires of the student-as-consumer. However, I argue that this market-centred justification neglects the further potential that novels and other media can have in this debate; using literature in pursuit of understanding "customer wants" (2) remains too closely aligned to close the "monochromatic discourse" (Collini 2012, 95) of contemporary policymaking. In the face of league tables, accountability indexes, and the impact agenda, it is evident that within the formal structures of the academy "there is no outside" (Foucault 1975, 331) of the discursive power of empirical valuation. However, humanities scholars should be attentive to alternative indicators that might open up new possibilities in the articulation of value. Stuart Hall develops Michel Foucault's hypothesis on discursive power in "The West and the Rest: Discourse and Power"

(C) The Author(s) 2020

Z. H. Bulaitis, Value and the Humanities, Palgrave Studies in Literature,

Culture and Economics, https://doi.org/10.1007/978-3-030-37892-9_4 
(1992) arguing that "discourse is about the production of knowledge through language. But it is itself produced by a practice: 'discursive practice' - the practice of producing meaning. Since all social practices entail meaning, all practices have a discursive aspect" (201). What follows in this chapter is an investigation into an alternative discourse of value is that developed through representing the value of the humanities in academic fiction. ${ }^{1}$ Such literary scholarship can challenge the linear shift towards economic discourse. I argue that the act of telling tales is an important way of reasserting more imaginative values. In "University Life in English Fiction" Philip Hobsbaum describes how "it is in fiction that experience tends to be most vividly rendered. It is this concern for the individual that tends to be left out of our discussions about universities. What one misses among the statistics is the human sense of the place" $(2006,20)$. He argues that concentrating on policy alone overlooks the human experience of education: fictional discourse captures values that white papers cannot. "A white paper can give us the general pattern, but it may not tell us how it feels to be an undergraduate" (20). This chapter explores the kinds of storytelling that represents value in higher education, and argues that the value of the humanities can be articulated through engagement with literary representation. The chapter is divided into three sections: the first part outlines why using academic fiction is a good tool to discuss the marketisation of higher education; the second part defines the genre of academic fiction and explores its enduring appeal; the third part provides three literary readings that build upon the theory and context outlined in Sects. 4.2 and 4.3 .

\subsection{Part I: Using Academic Fiction as a Discursive ToOl}

Using academic literature as source material for understanding the value of higher education is an emergent but growing field of scholarship. Many publications since 2000 have pointed towards popular culture, including literary fiction, as a site for understanding public attitudes concerning higher education. ${ }^{2}$ To date, Elaine Showalter has provided the most

\footnotetext{
${ }^{1}$ The term 'academic fiction' refers to a corpus of novels concerning life within and around a university and represents a broader category than campus novels. See further discussion of terminology in Sect. 2.2.

${ }^{2}$ See Reynolds, P. (2014) vii-ix; Edgerton and Farber (2005); Tierney, W. (2002).
} 
extensive study of the varying political influences of campus fiction in Faculty Towers: The Academic Novel and its Discontents (2005). Showalter pairs specific decades with significant corresponding debates within the academy. Accordingly, the 1980s are "feminist towers" and the 1990s are "tenured towers", in response to the political and social changes of these times. Showalter identifies that "academic novels are rarely in sync with their decade of publication; most reflect the preceding decade's issues, crises and changes" $(2005,15)$. Following Showalter's schema relies on the retrospective forces of canonisation in order to plot key debates in the representation of universities. In these terms, literary encapsulation of the current situation (post-2010) in higher education is yet to be written. ${ }^{3}$

However, present changes within higher education are rooted in neoliberal policymaking initiated during the 1980 s, and therefore are reflective of a longer history of economisation in education in England. In The Academic Novel: New and Classic Essays (2007), Merritt Moseley pronounces that "academic novels since the rise of Margaret Thatcher reflect, or react to, the changes in status and funding for Higher Education" (14). As Chap. 5 details more extensively, the foundations of privatisation within cultural policymaking was initiated during Margaret Thatcher's administration. Frank Parkin's novel The Mind and Body Shop (1986) challenges the prevalence of neoliberal management in universities prior to the recent changes since 2008 (see Sect. 4.6.2). Therefore, I argue that drawing upon fiction published since 1985 can inform a reader about the effects of the marketisation of higher education today.

In an episteme where the value of higher education is increasingly measured through numerical data, turning towards an analysis of fiction goes against the current expectations. However, the process of rendering reality into academic fiction can be beneficial; the imaginative space of a novel allows for greater freedom of interpretation. Novels about universities act as funhouse mirrors within which humanities researchers can recognise their own values and actions. Although an apparent sign of "ultimate narcissism", Showalter admits that her "favourite academic novels are about English departments" $(2005,3)$. In fiction about the experience of contemporary university life, the humanities scholar is able to experience what

\footnotetext{
${ }^{3}$ Showalter titles the twenty-first century section of her book "Tragic Towers", thus reflecting the crisis narrative of humanities scholars who are fearful and defensive about the future.
} 
Victor Shklovsky describes as defamiliarisation (ostranenie). ${ }^{4}$ The mundane is made strange in the process of fiction. This is, in fact, a tactic suggested by a character in David Lodge's academic novel Small World (1984). Professor Morris Zapp, a fictional highbrow literary critic, refers to the notion of "ostranenie" (77) as a solution to the monotony of assuming one position in the world. Zapp explains how "literature was all about [defamiliarization]" and argues that "art exists to help us recover the sensation of life" $(1984,77)$. Throughout Lodge's novel, Zapp identifies the ways in which fiction enables a scholar to articulate parts of the human experience that are harder to articulate through other kinds of writing about the humanities, such as critical theory or historical analysis.

Reading academic fiction in this way takes the realities of higher education and transforms them into new objects of study. Assuming the theory of ostranenie, the novel is able to invoke fresh conversations, from defamiliarised perspectives, concerning the values of the humanities. Cleanth Brooks and Robert Penn Warren argue, in line with Shklovsky, that "the fictional form [actually] gives point and definition to the social commentary" $(1959,76)$ as opposed to being "simply 'dress[ing] up' a specific comment on human nature" (76). They reason that the relationship between fiction and reality is capable of productive potential. John Gardner explains the way in which

\begin{abstract}
we recognize art by its careful, thoroughly honest search for and analysis of values. It is not didactic because, instead of teaching by authority and force, it explores, open-mindedly, to learn what it should teach. It clarifies, like an experiment in a chemistry lab, and confirms. As a chemist's experiment tests the laws of nature and dramatically reveals the truth or falsity of scientific hypotheses, moral art tests values and rouses trustworthy feelings about the better and the worse in human action. $(1978,19)$
\end{abstract}

Whilst much scholarship to date has focused on how academics are represented within the genre, academic novels also contain political commentary and criticism of other aspects of the university system. The work of the humanities is as worthy as the "chemist's experiment"; however, it is necessary to employ a different methodology since such work seeks to articulate a complex web of values, beyond simple "truth or falsity" (Gardner 1978, 19). In order to better understand the uses of academic novels, Sect. 4.3 of this chapter defines academic fiction as a distinct category of literary work.

\footnotetext{
${ }^{4}$ See Shklovsky, V. “Art as Technique” (1917).
} 


\subsection{Part II: Defining Academic Fiction}

This section presents a summary of the appeal of academic fiction, discusses popular settings, and examines the relationship between subject matter and formal style within the genre. In contemporary scholarship concerning fiction about universities, the term academic novel is preferable to campus novel since many stories are set beyond campus grounds, in archives, at home, or at elegant soirées. ${ }^{5}$ Therefore, the phrase academic fiction is used throughout this discussion to refer to the genre of novels that represent university life in this wider sense.

\subsubsection{Understanding the Appeal of Academic Fiction}

In a humorous article published in the Times Higher Education, 16 August 1996, Adrian Mourby asked: "Why did solicitors never capture the popular imagination? Whatever happened to the dental novel? What's wrong with accountants?" (1996). Academic fiction has a long history of enduring appeal. ${ }^{6}$ However, the Victorian period saw an increasing number of literary works make reference to university life and scholarship as educational institutions proliferated in England. In Postwar Academic Fiction: Satire, Ethics, Community (2002), Kenneth Womack draws attention to the nineteenth-century tradition of satirical fiction predominantly centred on undergraduate life at Oxbridge. ${ }^{7}$ Educational reforms during the nineteenth century led to greater attention being paid to the significance of higher education in the work of Charles Dickens, George Eliot, Thomas Hardy, and Anthony Trollope. In "On English Prose as a Rational Amusement" (1870) Trollope observed that "we have become novel reading people" (108). Later, in his autobiography, he reflected on the impact of his own academic fictions, suggesting how Barchester Towers (1857) had "become one of those novels which do not die quite at once, which live and are read for perhaps a quarter of a century" $(1883,139)$. Trollope was overly conservative in his estimation of the longevity of his readership. Increased literacy and broader distribution of literature meant

\footnotetext{
${ }^{5}$ I follow the definition of "campus novel" and "academic novel" outlined in Moseley (2007) viii, see similar definition in Williams, J. J. (2012b, 561-2).

${ }^{6}$ In fact, academics have been represented in fiction since antiquity; see Aristophanes' satire of Athenian intellectual fashions in The Clouds (423 BC).

${ }^{7}$ For further discussion of Victorian satire concerning universities see Proctor, M. (1957) 11-50.
} 
that early academic fiction was, and remains today, widely read. Thomas Hughes' Tom Brown at Oxford (1859), Max Beerbohm's Zuleika Dobson (1911), and Willa Cather's The Professor's House (1925) are examples of early academic novels that remain in print. ${ }^{8}$ Beyond this, the late-nineteenth and early-twentieth century saw the expansion of the broader category of the Künstlerroman [artist's novel] in English literature with prominent examples such as Henry James' Roderick Hudson (1875), James Joyce's $A$ Portrait of the Artist as a Young Man (1916), and F. Scott Fitzgerald's This Side of Paradise (1920). The significance of nineteenth-century literary and intellectual culture is also represented in the subject matter of contemporary academic fictions. Showalter recognises that "many of the most successful academic novels of the past fifty years have been rewritings of Victorian novels" (9). For example, Nice Work (1988) by David Lodge is a rewriting of Elizabeth Gaskell's North and South (1855) and A. S. Byatt's Possession (1990) is an ode to Victorian correspondence and literary lives. ${ }^{9}$

The emergence of the canon of academic fiction in England is cited to have emerged following the Second World War. ${ }^{10}$ George Watson argues that in the 1950s the genre "started what by now looks like its continuous life with C. P. Snow's The Masters in 1951 and Kingsley Amis's Lucky Jim two years later" (42). Showalter's survey in Faculty Towers also begins with the same two examples of Snow and Amis (see "Ivory Towers" 2005, 17-41). Clearly, to credit Amis (or to F. R. Leavis' imagined horror, Snow) with the foundation of an entirely new genre is erroneous, given the longer history identified above. Nevertheless, post-war academic fiction possesses certain distinctive properties that Amis was among the first to draw upon. Focusing on professors as opposed to students was a significant shift, as was the inclusion of a whole cast of academics as opposed to a single character study. Visiting Philip Larkin at University College in Leicester during the spring term of 1946, Amis encountered inspiration in the common room. ${ }^{11} \mathrm{He}$ describes the moment when he realised the

\footnotetext{
${ }^{8}$ Although Tom Brown at Oxford is only available in an edition with the more widely read Tom Brown's Schooldays published by Wordsworth (1993).

${ }^{9}$ Showalter's Faculty Towers also cites George Gissing's The Odd Women (1893) which was reworked by Gail Godwin in The Odd Woman (1974) see Faculty Towers $(2005,9)$.

${ }^{10}$ For American fictions see Mary McCarthy's The Groves of the Academe (1952), Randall Jarrell's Pictures from an Institution (1954), and Vladimir Nabokov's Pnin (1957).

${ }^{11}$ Larkin also authored an academic novel, albeit from a student perspective, in Jill (1946) written between 1943 and 1944, when he was an undergraduate at St John's College, Oxford.
} 
underutilised potential of using academic characters in fiction, reflecting how, "I thought at once, 'Christ, somebody ought to do something about this" (1973, 847). Amis reflects on this pivotal moment further in Memoirs (2004) as being the moment of discovering "a whole mode of existence no one had got onto from outside" (56) with a cast of ready-made characters.

Since Amis, Malcolm Bradbury and David Lodge became two of the most renowned authors within the genre, achieving popularity with The History Man (1975) and Changing Places (1975), respectively. Recognition of academic novels in literary prizes provided further proof of the success of the genre in the late-twentieth and early-twenty-first century. For example, Byatt's Possession: A Romance won the Man Booker Prize in 1990. Ana-Karina Schneider describes the novel as a "fetishisation not only of the written word but of any object associated with writing, and with its well-rehearsed scepticisms and theory-informed wrangling over meaning" $(2016,5)$. Despite being a novel entirely about the processes of studying English, Possession captured the popular imagination beyond academia. The success of contemporary academic fiction in terms of readership and prizes suggests that academic life is an alluring setting for the public. A 2015 YouGov survey of "The Most Desirable Jobs in Britain" affirms the enduring popularity of the academic profession as a desirable life choice amongst the general population. In analysing the YouGov survey, Will Dahlgreen identifies "an aura of prestige still surround[ing] the quiet, intellectual life enjoyed by authors, librarians and academics" (2015). The survey was based on responses from 15,000 UK citizens, $51 \%$ of whom stated that they would like the job of an academic, placing it in the top three jobs for both the women and men surveyed (see Fig. 4.1). The top three jobs all involve working with books. Dahlgreen notes that the results suggest that respondents prefer jobs that involving deskwork, some degree of personal choice, and space for scholarly thought.

Terry Eagleton offers an excellent account of the popularity of campus fiction in his essay "The Silences of David Lodge" published in the New Left Review in November 1988:

the university has the glamour of the deviant and untypical, providing the novelist with a conveniently closed world marked by intellectual wrangling, political infighting and sexual intrigue. Yet in its bureaucratic routines and down-at-heel dreariness it is also sufficiently continuous with the wider society to act as a microcosm of middle-class mores. It is neither too hermetically sealed from the social order to be of merely specialist interest, nor too 
Fig. 4.1 "The Most Desired Jobs in Britain." YouGov UK Survey, 12-13 January 2015

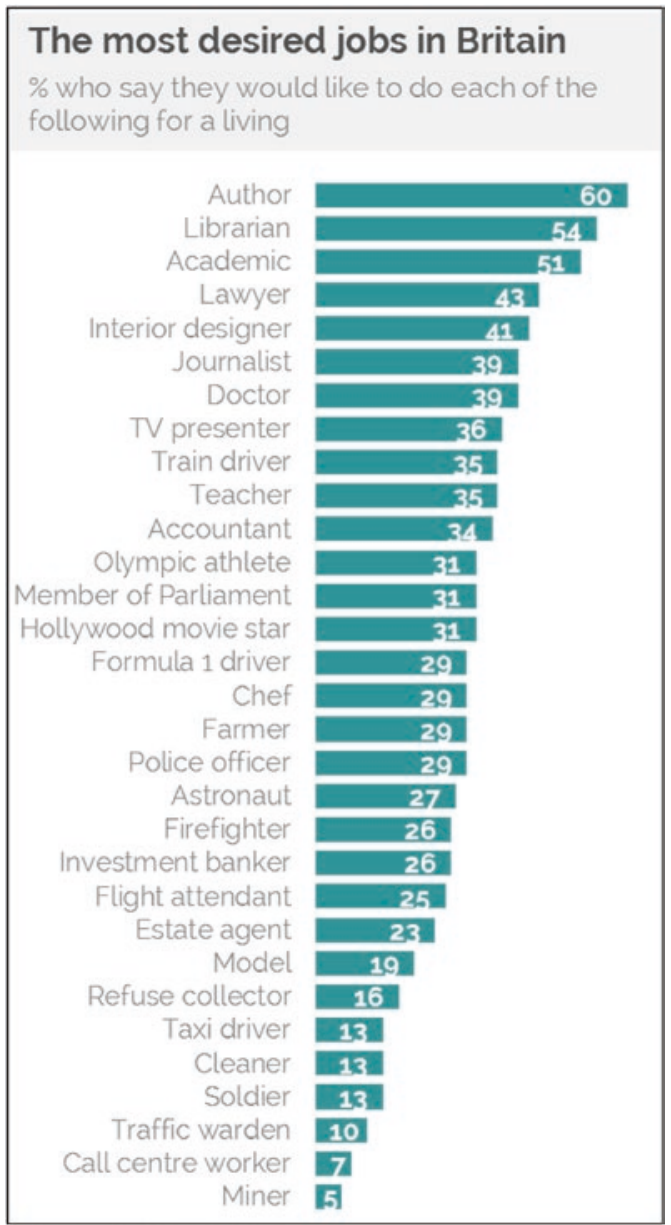

commonplace to be merely tedious. The 'campus' novel thus provides one kind of solution to a problem which has never ceased to dog the modern English novel, and which is nothing less than how ordinary social experience is to offer a fertile soil for fictional creation. (93)

Here, Eagleton demonstrates how an academic setting for fiction allows a precarious balance between the general and the particular to be achieved. David Lodge famously maintained that "the university is a kind of 
microcosm of society at large, in which the principles, drives and conflicts that govern collective human life are displayed and may be studied in a clear light and on a manageable scale" $(1986,169)$. Therefore, it might be understood that the changes felt within a university are representative of wider social transformations beyond the campus. The scaling down of societal concerns within the microcosm of a university allows for intervention in an otherwise unmanageably large or abstract context.

The imaginary and contained world of the campus novel also serves as a common reference point. Readers of academic novels today are likely current or former undergraduate students. The rapid increase of student numbers, up $44 \%$ in the last fifty years, is a result of the expansion of higher education, meaning that many readers today can relate to representations of universities in fiction. Writing in the Chronicle of Higher Education, 22 September 2000, Jay Parini affirms that “today's readers were once students themselves, and they still wonder what went on behind closed office doors and in the homes of their professors" (13). An interest in understanding what happens behind the scenes only increases as higher education institutions appear more professionalised and corporate from the perspective of the undergraduate student. The appeal of academic fiction may continue to grow as increasing numbers of young people become graduates, leave higher education, and look towards fiction as an opportunity to reflect, for better or worse, on their experience of the university.

\subsubsection{Situation and Settings for the Academic Novel}

In Literature Against Criticism: University English and Contemporary Fiction in Conflict Martin Paul Eve argues that "the academy is woven more broadly and more deeply into the fabric of the contemporary fiction scene than might be supposed were an investigation limited to works that focus on depictions of the university" $(2016,19)$. Whether located on or off campus, the most frequent setting within which to reliably locate the academic novel is amongst the social interactions of an English department. ${ }^{12} \mathrm{~A}$ list of the most renowned academic fictions highlights how this discipline dominates. Mary McCarthy's The Groves of Academe (1952), Kingsley Amis' Lucky Jim (1954), John Williams' Stoner (1965), David

\footnotetext{
${ }^{12}$ There are, of course, many examples from other disciplines. See for example, Bradbury's The History Man (History); Delillo's White Noise (Hitler Studies); Tartt's The Secret History and Roth's The Human Stain (Classics).
} 
Lodge's campus trilogy (1975-88), Michael Chabon's Wonder Boys (1995), and J. M. Coetzee's Disgrace (1999) all place an English faculty at their centre. Since the millennium, there has been a further proliferation of English professors represented in literary fiction including Percival Everett's Erasure (2001), Roberto Bolaño's 2666 (2004), and Michel Houellebecq's Submission (2015). The following discussion considers why the subject of English is such used so recurrently in representing scholarly life in contemporary academic fiction.

Steven Connor observes that "the fact that most campus novels tend to be about English teachers or students [...] is of course not very surprising even given the hostility to traffic or fraternization between the critical and creative realms characteristic of the teaching of English literature since the War" (2001, 70). Many authors of academic fictions held creative writing posts within literature departments, including Amis (predominantly University of Wales, Swansea), Bradbury (University of East Anglia) and Lodge (most famously at the University of Birmingham). ${ }^{13}$ The emergence of undergraduate and postgraduate creative writing courses within English departments further solidified this bond. Bradbury conceived of and established the first British creative writing course at the University of East Anglia (UEA) in 1970. ${ }^{14}$ To date, the Complete University Guide lists over 500 undergraduate and over 400 postgraduate creative writing courses available in 2015-16. ${ }^{15}$ Therefore, the dominance of English professors may be a result of the write what you know approach to creative writing. ${ }^{16}$ Michael Frayn, author of the academic novel The Trick of It (1989), speculates that "ninety seven per cent of novelists were once themselves students $[\ldots]$ and believe they could have been academics themselves, if only they had not had better things to do than write weekly essays and pass exams" (qtd. in Mourby 1996). The continued experience

\footnotetext{
${ }^{13}$ Further contemporary examples include Zadie Smith drawing on Harvard (On Beauty 2005 ) and Philip Hensher's inspiration at the University of Exeter (King of the Badgers 2011).

${ }^{14}$ The formalisation of the creative writing within universities has deeper historical roots in the US than in Britain. The University of Iowa Writers' Workshop was the first creative writing degree program in the US and was founded in 1936.

${ }^{15}$ This includes postgraduate taught and research programmes.

${ }^{16}$ Giles Foden, Professor of Creative Writing at the University of East Anglia, describes how "ninety-four British universities offer a range of postgraduate degrees in creative writing and in any one year there are usually more than 10,000 short-term creative writing courses or classes on offer in the UK" (2011).
} 
of life within an English department has a bearing on the minds of several generations of writers of academic fiction.

Further correlation between authors and literary academics is found beyond the formal instruction provided by universities. For instance, many contemporary novelists depend on the university environment as a source of financial support for their writing career. The Royal Literary Fund's Fellowship Scheme explicitly encourages professional writers to work within universities. The fund's founder, Hilary Spurling describes how the programme aims to "break down divisions, build up contacts and stimulate the living language, to relieve cultural poverty and linguistic distress as well as lightening the financial and material pressures weighing so heavily at present on the whole company of authors" (1999). Spurling expresses the desire for academics and authors to connect in order to generate better creative and critical work, despite the economic pressures of the time.

Matthew Arnold's The Function of Criticism in the Present Time (1865) ranks the art of creative writing above that of academic, or critical, work: "the sense of creative activity belongs only to genuine creation; in literature we must never forget that" (51). However, Arnold observes how "the grand work of literary genius is a work of synthesis and exposition" which is reliant on a "certain intellectual and spiritual atmosphere, by a certain order of ideas" (28). Applied to the relationship between novelists and universities in England today, writers within humanities departments are synthesisers who are able to expose values of their educational environment within literary creation. Academic fiction finds its "certain intellectual" home within the English department. However, in addition to the practical associations outlined above, I propose a secondary reason as to why English is the recurrent site for academic fiction: the processes of reading and critique are inherent in the practices of the discipline. "We should begin to read these novels less in terms of their actual brilliance or success" argues Janice Rossen, "and more in terms of what they reveal about the dynamics of power between the contemporary novelist and his audience" $(1993,188)$. Considered in this manner, the work of academic fiction as critique bears similarities to the work of scholarly literary criticism. Novels are explorations of literary expression, and the subject of English offers the closest affinity within the academic humanities.

Eve's Literature Against Criticism goes as far to position English and contemporary fiction as being in direct competition. He explores how novels about academics can be considered metafictional in their use of "a series of novelistic techniques that [... function to outmanoeuvre, 
contain, and determine academic reading practices" (2016, 15). Novels about universities, Eve argues, represent an "anxiety of academia within the space of literary production" (16). Contemporary fiction is not hampered with by same fears or constraints and is, therefore, able to operate within the literary marketplace more successfully. The examples of contemporary novels in Literature Against Criticism offer a convincing exposition of an anxiety within the academy, that novelists could better do the work of social critique than the critics themselves. Eve examines how in contemporary fiction, a postmodern scepticism for institutional authority combines with the kind of novelistic "knowing" inherent in Joyce's "many enigmas and puzzles that will keep professors busy for centuries arguing over what I meant" (qtd. in Ellmann 1982, 521). Should university English be concerned about the success with which contemporary fiction conveys literary kinds of knowledge? Eve concentrates on locating the academy within the market wherein "academic aesthetic judgement form $[\mathrm{s}]$ only a weaker correlative portion of the gatekeeping system" $(2016,22)$ of literary knowledge production. However, this chapter takes a wider survey of the genre of academic fiction and avoids market-centred discussions oriented around publishing, sales, and literary prizes. Rita Felski notes that, in the discipline of English, "the works that we study and teach $[\ldots]$ could never come to our attention without the work of countless helpers" within the literary industry, including "publishers, advertisers, critics, prize committees, reviews" $(2015,170)$. However, her list concludes: "last, but not least, the passions and predilections of ourselves" (170). Instead of regarding the relationship of literature and university English the context of the market, in competition with one another for literary authority, scholars might pursue a more collaborative (and Arnoldian) symbiosis with fiction.

Beyond the competition of publication and sales in the literary sphere, novels do offer something different from academic research. Academic novels create imaginative reflections of higher education that are not beholden to the realities of the present. In turning away from a discussion of economic value, and refusing to speak only in these terms, humanities scholarships can be "jolted out of this kind of numbed acquiescence and reminded that words are our masters as well as our servants" (Collini $2012,95)$. If we accept that "words are our masters" then it is imperative to explore a vernacular that extends beyond "competition", "ranking", "growth", and "excellence". As Chaps. 2 and 3 have already demonstrated, an alternative expression of value is lacking in contemporary 
policymaking. This is not the case within contemporary fiction. The next section demonstrates how the formal properties of the academic novel are essential to this generative representation while paying specific attention to how these formal properties engage with representations of the humanities.

\subsubsection{Subject Matter and Style in Academic Fiction}

Academic fictions are primarily focused on the lives, concerns, and interactions of academics. In Imagining the Academy, Edgerton explains that "I know that life as a professor is a privileged life in so many ways [with] work that can challenge and reward one's creative spirit" $(2005,1)$. Edgerton recognises the appeal of an academic life that allows for intellectual debate and philosophical reflectiveness. Although students appear in most academic fictions, the central characters are those that Showalter calls "the lifers" $(2005,2)$. Whilst being a student is only ever a transitional and temporary state, the experience of being an academic is more permanent. ${ }^{17}$ In 1980, Richard Caram coined the term Professorroman, an adult counterpart to the juvenile bildungsroman, to describe a novel which follows an academic's life. ${ }^{18}$ In the bildungsroman, a reader follows an individual's formative years. Ensuing follies and faults are overcome, with the naivety and errors of youth being part of the necessary journey to adult responsibility. However, no such relief is permitted for the protagonist of the Professorroman who has already attained the supposed wisdom of adulthood.

John Williams' Stoner (1965) is an illuminating example of the Professorroman. The novel tracks the life of William Stoner, from his application to study as an undergraduate at the University of Missouri to his reflections at the end of his life and career. Stoner describes his research as "a haven, an excuse to come to the office at night. He read and studied, and at last came to find some comfort, some pleasure, and even a ghost of the old joy in that which he did, a learning toward no particular end" $(1965,131)$. Here the reader gains an insight into the process of unending pursuit of learning that is inherent in an academic life, as opposed to an academic job. Writing for the Times Higher Education, Christopher

${ }^{17}$ That is not to say that novels about student life, such as Philip Larkin's Jill (1926), or David Nicholls' Starter for Ten (2003), do not offer representations of university life that are equally worthy of study. For discussion of student representations in academic fiction see Walkerine, V. (1990); Edgerton and Farber (2005); Deresiewicz, W. (2007); Terzian and Ryan (2015).

${ }^{18}$ See Caram, R. $(1980,42)$. 
Bigsby argues that "the value that Stoner ascribes to literature, to a precision of language, each word in its place, is that to be found in this novel, which is remarkable precisely to the degree to which it is unflinching in its observation and stunning in its humanity" (2013). Here, Bigsby raises an important point that Stoner identifies the benefit of a life spent in the humanities, not simply through its content but also through its form. The novel encapsulates a vision of slow and steady scholarship and "learning toward no particular end” (Williams 1965, 131). As Williams' explains about his creation of Stoner: "he might not have been a very good teacher, but that didn't matter much. He was witness to values that are important" (qtd. in Asquith 2017, 110). The novel explores the lack of fanfare surrounding the action of upholding academic integrity and a quiet solace that can be found in a life in literature.

Stoner is a novel that has only recently achieved popular acclaim and critical recognition. First published in 1965, a second edition was not published until 2003. In Reading the Novels of John Williams: A Flaw of Light (2017), the first scholarly monograph to exclusively focus on John Williams' literary works and life, Mark Asquith argues that the renaissance of Stoner was a "peculiarly European affair" (3), despite being heralded as a great American novel. He notes how this may be in part due to the attention that the French novelist, Anna Gavalda, gave to the text in 2011, in buying the rights and translating the text from English to French before publishing the book with her name on the flyleaf. Gavalda reflects that "when all the other European editors saw that it was me who translated this book, they were all curious about why Anna Gavalda translated it, and so they all bought the rights" (qtd. in Asquith 2017, 2). Asquith's opening chapter charts "the Stoner phenomenon" (2) that took place between 2011 and 2013 when Williams' seldom read title became Julian Barnes' "must read novel of 2013" ( The Guardian 2013) and Tim Kreider's "The Greatest American Novel You've Never Heard Of" (The New Yorker 2013). The renewed popularity of such a novel in this period of rapid change to higher education is noteworthy. Writing in The Globe and Mail, Sarah Hampson observes that perhaps,

it is simply a matter of a book finding its perfect moment. We live in an era in which happiness and success are pursued ruthlessly, selfishly. We feel entitled to have them, at any cost [...] this is a novel that serves as an antidote to that expectation, reminding us that a life that looks like a failure from the outside, that will be quickly forgotten once it ends, can be a noble, quirky and somehow beautiful experience. (2013) 
Stoner offers an alternative expression of experience within a competitive and task-oriented research climate. Academic fictions that document an entire life are able to represent the experience of humanities scholarship on a scale that would be impossible to articulate in its lived practice. Fictions are, therefore, able to capture values within the academic experience that might otherwise remain elusive.

Martha Nussbaum discusses the connection between the novel form and lived experiences in Love's Knowledge, arguing that the novel can act as an education in liberal values. She observes that in a novel "form and style are not incidental features. A view of life is told" $(1990,5)$. Nussbaum argues that the formal properties of a novel are tied to the values it conveys and, in fact, assists in generating those values. She notes how:

the selection of genre, formal structures, sentences, vocabulary, of the whole manner of addressing the reader's sense of life - all of this expresses a sense of life and of value, a sense of what matters and what does not, of what learning and communicating are, of life's relations and connections. Life is never simply presented by a text; it is always represented as something. $(1990,5)$

The articulation of the value of the humanities in an academic novel is not only conveyed in the subject matter but also in the style and space of the story. In his meditation on the experience of reading in The Space of Literature, Maurice Blanchot observes that "language is affirmed in literature with more authority than in any other form of human activity. [...] Words, we know, have the power to make things disappear, to make them appear as things that have vanished" $(1982,43)$. In The Space of Literature, fiction creates the opportunity for liminal and imaginative space in which ideas can be created and communicated. Blanchot describes how "the work is a work only when it becomes the intimacy shared by someone who writes it and someone who reads it, a space violently opened up by the contest between the power to speak and the power to hear" (37). Fictional writing is transformative in its ability to articulate both particular ideas and general values. Within the specific setting of an academic novel, the day-to-day actions essential to convincingly representing life in a university are combined with broader philosophical and literary enquiries. For example, Smith's On Beauty uses a domestic affair and an academic rivalry as a reconsideration of the relationship between critical and aesthetic theory (see Sect. 4.6.3). Smith finds an environment with a small enough scope to summon realistic details and the benefit of the freedom 
to ask large philosophical questions about value. The campus, or even more precisely, the corridors in the English department provide a particular space in which to tell a story that can represent certain values.

The third part of this chapter turns to a series of fictional explorations. Unlike analysis of characters within literature the following readings expose the disciplinary character of the humanities. Although it is possible to tease out impressions of the humanities from a great many campus novels, the specific examples selected allow for depictions of value to shine most intensely. Previous scholarship has provided extensive taxonomies of academic fiction (see Carter 1990), general surveys (see Moseley 2007), and histories of genre development (see Showalter 2005). Here, I offer a specific selection of academic fictions that best articulate the value of humanistic learning and life. I draw upon a range of academic fictions from the nineteenth to the twenty-first century. First, the analysis of Thomas Hughes' Tom Brown at Oxford (1859) and Donna Tartt's The Secret History (1992) initiates an examination of the qualities of a liberal education in the humanities. The second section analyses the lived experiences of humanities scholarship in George Eliot's Middlemarch (1871) and A. S. Byatt's Possession (1990). Here, the connection between the physical action of scholarship and a more philosophical reflection of value is explored at length. The third and final investigation interrogates the context of economisation from Thomas Hardy's Jude the Obscure (1894), to contemporary examples of Frank Parkin's The Mind and Body Shop (1986) and Zadie Smith's On Beauty (2005). In doing so, I explore the potential of reading fictions as a tool to disrupt the monotonous language of economic profit. The following three investigations collectively reveal a rich field of representation of the character of the humanities. I use the word 'investigation' as each section asks a specific question of the academic novel: first, how do representations rooted in history and nostalgia represent the humanities? Second, in what ways can novels articulate the processes of scholarship, and the benefits that such a pursuit creates? Third, how can novels critique economic norms and create space for alternative values in education?

\subsection{Part III: Investigation One: The Qualities of A LibERAL EDUCATION}

Despite a resolve to focus on "the lifers" (Showalter 2005, 2), the fictional examples in this investigation centre on the experience of education from a student's point of view. I argue that in representing humanities 
teaching, the abstract ideas that surround the qualities of a liberal education are made evident. Without the student, a representation of an educator is redundant. Therefore, in this specific instance, student-led academic fiction plays an active role in articulating the values of the humanities. Hughes' Tom Brown at Oxford (1859) provides an exemplary Victorian account of the qualities of an Oxford education whilst Tartt's The Secret History establishes a contemporary account of an equally exclusive liberal education. There are a number of similarities between the novels; they present closed-off worlds nostalgic for a bygone era and explore educational spaces in which young people learn more about living a valuable life than attaining any measurable qualification.

\subsubsection{The Qualities of an Education in Tom Brown at Oxford}

Tom Brown at Oxford, a less well-known sequel to Tom Brown's Schooldays (1857), was first serialised in Macmillan Magazine in 1859. It provides a nostalgic account of the experiences of the protagonist, Tom Brown, during his time as an undergraduate at the University of Oxford. The setting of Oxford is significant for the author Thomas Hughes, who, as his father before him, attended Oriel College from 1842-45. The novel is set in the 1840s when Hughes was a student and there are semi-autobiographical connections between the author and the young protagonist. Tom Brown at Oxford describes the city of Oxford in idyllic terms; Tom recounts how "the first few days I was delighted with going about and seeing the buildings, and finding out who had lived in each of the old colleges, and pottering about in the Bodleian, and fancying I should like to be a great scholar" $(1859,284)$. The architecture contributes to the academic experience of an Oxford education. Tom's close friend Hardy describes a panorama of the city in similar terms: "the spires and towers $[\ldots]$ and the river in the foreground. Look at that shadow of a cloud skimming over Christchurch Meadow. It's a splendid old place after all" (Hughes 1859, 468). These expressions of the picturesque fuel the idea of Oxford as an exclusive world. The implication of exclusion from Oxford is explored through architectural metaphor in Jude the Obscure, which will be discussed at length below (see Sect. 4.6.2).

Oxford, "that sweet city with her dreaming spires" (Arnold 1866, 19), is frequently used as a physical representation of scholarship and the power 
of learning in academic fictions. ${ }^{19}$ John Dougill's Oxford in English Literature examines the ways in which the city has been represented in literature. He explains how "for over six hundred years the portrayal of Oxford in poetry and prose has made the city as much of a fiction as an actuality, a representation as well as a reality" $(1998,1)$. Oxford is arguably the most popular setting for fictions that involve a university. Ian Carter's account of campus fiction in Ancient Cultures of Conceit (1990) places the number of post-war 'Oxford novels' at over one hundred, which Dougill calculates to be at least "three a year" (86). Brian Harrison observes that "16 of the university novels published between 1945 and 1988 were set in Cambridge, though Oxford boasts 119" (1995, 1328). In general, fictional representations of the University of Oxford are kinder than those of the University of Cambridge. Cambridge is perhaps most famously fictionalised in the political infighting of C. P. Snow's The Masters (1951) and Tom Sharpe's Porterhouse Blue (1974). Oxford is afforded more idealistic visions, such as Max Beerbohm's Zuleika Dobson (1911); references in the poetry of Matthew Arnold, such as "Scholar Gipsy" (1853) and "Thrysis" (1865); and the fictional Christminster in Hardy's Jude the Obscure (1894).

In Liberal Intellectuals and Public Culture in Modern Britain, 1815-1914 William Lubenow describes how "nineteenth-century Oxford and Cambridge were symbolically significant because they were sites in which liberal values were publically represented" $(2010,29)$. Hughes' novels about archetypal schoolboy Tom Brown present a clear vision of such a liberal education. Throughout Tom Brown's Schooldays (1857) and Tom Brown at Oxford (1859), precise knowledge is secondary to the civilising and social forces an education provides. A direct appeal to the reader illustrates this textual ambition: "Reader! Had you not ever a friend a few years older than yourself, whose good opinions you were anxious to keep? A fellow teres atqua rotundus [complete in himself]; who could do everything better than you, from Plato and tennis down to singing a comic song and playing quoits?" (Hughes 1859, 269). The description of the senior student, Saunders, as a teres atqua rotundus draws attention to the result of liberal education creating a well-rounded individual. The wideranging admiration from Greek philosophy to garden games draws

\footnotetext{
${ }^{19}$ For more popular examples, see Pullman, P. His Dark Materials trilogy (1995-2000) and Dexter, C. Inspector Morse (1975-99), which was also the basis for a long running TV show (1987-2000).
} 
attention to the broad pool of references which Oxford provided its graduates with. Tom Brown's Schooldays similarly suggests that who education teaches you to become is more important than what you learn. This generalist approach is exemplified in the attitude of Tom's father, Squire. When Tom is sent to Rugby for the first time, Squire states that "I don't care a straw for Greek particles, or the digamma [...] what is he sent to school for? Well, partly because he wanted so to go. If he'll only turn out a brave, helpful, truth-telling Englishman, and a gentleman, and a Christian, that's all I want" $(1857,63)$. The qualities of an education are the benefit as opposed to the acquisition of academic knowledge. Squire is unconcerned with discrete units of information, of "particles", but instead in the process of self-development that a liberal education encourages. These qualities of bravery, honesty, and willingness are the aspirations that Tom's father has for his son in the system of education. In Tom Brown at Oxford, Hughes informs the reader that "the body of fellows of St. Ambrose was as distinguished for learning, morality, and respectability as any in the University" $(1859,246)$. Throughout the novel, Tom upholds a belief in the values such as "universal education" (604), "democracy" (672). The focus in both primary and higher education is for the cultivation of a type of person, rather than the attainment of specific knowledge.

Such aspirations and beliefs should not be considered at the level of the individual development alone or without an acknowledgement of nostalgia. In Subjectivities: A History of Self-Representation in Britain, 1832-1920, Regenia Gagnier documents how young boys "were extruded from their homes at the age of eight for all-male prep schools that funnelled them into public schools and the socialized and oedipal transferences of power. They learned in school to be boys without women, then to be masters of other boys, and then to be the guardians of state and empire" (1991, 178). Considered at this scale, both Hughes' Tom Brown's Schooldays and Tom Brown at Oxford contribute to the creation of nostalgia for a system that was exclusive and first and foremost served the needs of the nation rather than the individual. Gagnier points to Jonathan Gathorne-Hardy's study The Public School Phenomenon (1977) as further evidence that "segregation into a one-sexed environment is the single most important social factor distinguishing the British upper classes from the lower" (Gagnier 1991, 186) in addition to “distinguishing Britain's national male-bonding for power, or homosociality, from that of other Western societies" (186). Such considerations of gender and class trouble the vision of a liberal education that Hughes presents. Tom Brown at Oxford 
may well represent an expression of non-instrumental learning and the pursuit of an "age of peace and good will which men had dreamt of in all times" $(1859,672)$, but the delineation of men alone, and not even all men, should be clearly recognised.

The context in which Hughes imagines the benefits of liberal education is very different to the current state of higher education in England. At a national level, a specialised education has surpassed the ambition for a general one. Today, the government and multinational companies recruit undergraduates into areas of skills shortages. ${ }^{20}$ As described in Chap. 2, the Browne Report (2010) explicitly identified that clinical and STEM subjects as priorities for funding and student support. Within this system of valuation, an emphasis is placed on the wellbeing of society, especially through a focus on healthcare and infrastructure rather than on the individual learner. Hughes' aspiration for a "fellow teres atqua rotundus" $(1859,269)$ is unrecognisable within the demands of the current economic framework. It is no longer a national interest to cultivate liberal subjects, but rather precisely skilled workers.

Although the prevalence of the market and present-day demands for specialism are largely absent in Hughes' novel, there are a few inferences towards an encroachment of economic motivations in Tom Brown at Oxford. The most significance observation is made towards the end of the novel when Tom laments the seeping of outside influences into his liberal education:

while one was an undergraduate, one could feel virtuous and indignant at the vices of Oxford, at least at those which one did not indulge in, particularly at the flunkeyism and money-worship which are our most prevalent and disgraceful sins. But when one is a fellow it is quite another affair. They become a sore burthen then, enough to break one's heart. $(1859,709)$

Even in a nostalgic novel set in the 1840s (before any substantial educational reforms concerning economisation) there is "money worship" (709) at work. Despite the aspiration of Hughes' protagonist towards an education without specific application, the menace of professionalisation exists even within the nostalgic Tom Brown at Oxford. Flunkeyism-the pursuit of menial tasks - stands in as the antithesis to Hughes' generalist model of education.

\footnotetext{
${ }^{20}$ For policy examples see Confederation of British Industry (2012); City and Guilds (2008); Mourshed et al. (2012); UKCES (2014).
} 
In Not for Profit, Nussbaum insists that it is imperative that students are offered a liberal education. This includes learning "how to inquire, and what questions to ask" $(2010,92)$. She reasons that "colleges cannot convey the type of learning that produces global citizens unless they have a liberal arts structure: that is a set of general education courses for all students outside of the requirements of the major subject" (93). Nussbaum argues that the humanities form a fundamental part of the necessary qualities of a liberal education. She upholds that the quality of studying "The Greats" offers a space away from specific application or utility in which to think about wider democratic concerns. While it is possible to learn factual knowledge elsewhere, "the ability to assess historical evidence, to use and think critically about economic principles, to assess accounts of social justice, to speak a foreign language" (Nussbaum 2010, 93) should be the responsibility of a university education. These qualities align with the aspiration that Squire has for Tom's future: “if he'll only turn out a brave, helpful, truth-telling Englishman" (Hughes 1857, 63). The aspiration towards a rounded education that aspires to teach students how to be citizens in the world is threatened in the contemporary system of education, which to encourages the acquisition of skills only in areas of shortage and in subjects that directly contribute to the economic wellbeing of the country. Such processes of specialisation are designed to attend to skills shortages, which undermine the importance of a general education.

Writing in 2013, Nel Noddings argued that educators need "to integrate important work from the liberal arts into every subject and track of the curriculum" (81) in order to preserve these general qualities of an education. Noddings cites Ernest Boyer's definition of integration as a way of "making connections across disciplines, placing the specialities in larger context, illuminating data in a revealing way, often educating nonspecialists, too. In calling for a scholarship of integration, we do not suggest returning to the 'gentleman scholar' of an earlier time, nor do we have in mind the dilettante" $(2013,81)$. That figures such as the "gentleman scholar" and "the dilettante" no longer have a secure hold in the contemporary academy is only a positive thing. However, Boyer's observation recognises qualities of a liberal education that should not be left behind. Although Tom Brown at Oxford is set within a privileged world, the suggestion that the experience or quality of education is just as (if not more) important as the subject matter acquired, is a lesson to be taken from the text today. John Guillory observes that 
if the liberal arts curriculum still survives as the preferred course of study in some elite institutions, this fact has everything to do with the class constituency of these institutions. With few exceptions, it is only those students who belong to the financially secure upper-classes who do not feel compelled to acquire professional or technical knowledge as undergraduates. $(1993,46)$

This exclusivity is frequently portrayed in academic fictions, especially in regard to the study of Classics that both Hughes' Tom Brown at Oxford and Tartt's The Secret History reference. However, Hughes' message of an education that encourages the development of liberal values beyond any particular application is important to consider. Although Latin instruction is currently beyond the remit of most state schooling, we should be cautious of the idea that education not immediately applicable to the marketplace should automatically be assumed to be elitist. Guillory states that this devaluation is the result of neoliberal governance. "The perceived devaluation of the humanities curriculum is in reality a decline in its market value" $(1993,46)$. Given the current economic austerity, it is hard to recognise the value of the long-term development of character that the Tom Brown novels exemplify and celebrate. Before turning to The Secret History, it is also important to note that Hughes' vision of education is problematic in the omission of women, international students, and large sections of the working class. Although it is unfair to apply contemporary beliefs to the past, that Hughes' moral education is exclusively male and set in an environment open only to a privileged few renders it a poor tool for addressing the present. However, I maintain that although more students are now able to access higher education in England, it need not correspond that "flunkeyism" $(1859,709)$ should be the adopted as the model for universities to follow. As Noddings argues, there are values in a liberal education that are yet worth fighting to preserve.

\subsubsection{The Secret History: A Classical Education Out of Time}

Tom Brown at Oxford focuses on the cultivation of a well-rounded individual able to apply himself (albeit not herself) towards some specific cultivation within civil society. Donna Tartt's The Secret History (1992) works in reverse, suggesting that an obsessive understanding of a particular subject-Greek-can act as the basis for understanding the wider world. Tartt's approach to representing education in this way is arguably further removed from utility, as the influences of national subject forming practices in the all-boys-club mentality of Oxford are replaced with an aesthetic appreciation of classical texts. 
The novel follows a clique of students enrolled in Professor Julian Morrow's Greek class. The action of the novel is shaped by Morrow's pedagogical and personal influence. In justifying his teaching methods, Morrow explains his belief that "having a great diversity of teachers is harmful and confusing for a young mind, in the same way, I believe it is better to know one book intimately than a hundred superficially" (1992, 32). This statement is not backed up with reference to contemporary pedagogic justification, but by Greek history: "I know the modern world tends not to agree with me, but after all, Plato had only one teacher and Alexander" (32). This example represents Morrow's belief that an education in the humanities is rooted in an understanding of the classical mind. Beyond the subject matter, the style of tuition and the modes of thinking are also modelled on antiquity. Morrow makes it clear that "diversity" (32) and superficiality are the results of "the modern world" and its neglect of ancient scholastic traditions. Whilst the vision of liberal education in Tom Brown at Oxford is generalised and concerned with civilising through homosocial bonding, the world of The Secret History is tied intimately to a precise understanding and re-enactment of the philosophy of the classical world. In "Failures in Classical and Modern Morality: Echoes of Euripides in The Secret History" Barbara Melvin observes that "the idea of one teacher is unthinkable in academia today, but in classical Greece was the norm" (1996, 53). The connection between Greek myth and the approach to teaching is one of intimacy in The Secret History. Tartt builds an imaginative space in which the reader experiences a singular teacher. The subject matter taught in the classroom is fused with the present lives and activities of the students outside of it. ${ }^{21}$ Hellenistic, Aristotelian, and Dionysian teachings are brought to bear on the social life and ideas of the novels central characters. It would be more accurate to say that Morrow's students live Greek philosophy as opposed to study it.

Through embracing Greek philosophy in the action of the novel, The Secret History offers a developed representation of education as a lived experience. A large proportion of the text is spent in the classroom and in the company of the novel's professor. Conventionally in student-centred texts, time spent in the classroom is minimal, while the majority of the action occurs in domestic and social spaces. The Secret History offers the

\footnotetext{
${ }^{21}$ Tartt's novel even takes its name from a Greek text authored by Procopius of Caesarea (550-558? CE).
} 
reader unusual access to an exclusive and romantic vision of teaching in the bohemian office of a selective Professor. Morrow has a "theory that pupils learned better in a pleasant, non-scholastic atmosphere [...] some sort of Platonic microcosm of what he thought a schoolroom should be" (Tartt 1992, 34). The fictional location of a small liberal arts college in America is the most natural home for this kind of education in fiction, and quite probably in the real world. A recent example of Professor Ricardo Dominguez's teaching at the University of California, San Diego suggests that there may still be space for non-conventional educative experiences within larger institutions. Dominiquez requests that his students attend one session of his course naked. The syllabus outlines that students are invited to "create a gesture that traces, outlines or speaks about your 'erotic self"” ("Visual Arts 104A: Performing for the Self" n.d.). Several newspapers allege that students perform naked by candlelight, with the Professor also being nude. ${ }^{22}$ This is evidence of how some scholars continue to reject a corporate approach in a belief that their subject matter requires an alternative approach.

Education is presented as a heightened form of living in The Secret History. Throughout, the teachings of the ancient world are applied to the lives of the students in Morrow's class. Tracy Hargreaves argues that this enables an understanding of "an important aspect of this novel [...] to do with human limitation, and the ability, as Julian had told them, to ever really know one another, or indeed, ourselves" (2001, 63). The ancient world, full of passion and meaning, is a more attractive alternative to the facile present. Through the eyes of the narrator, Richard Papen, the reader glimpses the substitute to the student experience of "drive-in movies and Mexican food, going to Tracy's apartment for Margaritas and MTV" (Tartt 1992, 429). The education afforded to other undergraduates at Hampden, such as Judy Poovey and Cloke Rayburn, leaves them with "bored smiles and sleepy eyes and cigarettes" (71). The passive and consumerist lifestyles represented by the students within The Secret History suggest that the experience of those studying the Classics is an anomaly across the campus. Morrow's mantra "what is unthinkable is undoable" (311 italics original) encourages the consideration of all possibilities. This pursuit of the sublime ends badly, with murder, gunshot wounds, and suicide. The vital enactment of the Nietzschean Übermensch and

\footnotetext{
${ }^{22}$ For example, see Allen, N. (11 May 2015) "Students asked to sit final university exam in nude with naked professor"; CNN (11 May 2015); CBS Local (11 May 2015).
} 
statements about "human limitation" (63) are made to be increasingly morally dubious when implicated in a crime and yet by the end of the novel, Tartt celebrates the pursuit of knowledge in place of the alternative model of education.

The intense experience of education offered by Tartt's novel is an unorthodox representation of the humanities. Although the novel reaches frenzy and murder, the presiding impression of the humanities students, and Morrow himself, is of coldness. In the opening chapter, the student narrator Papen admires the Greek students from afar. He describes how they "shared a certain coolness, a cruel, mannered charm which was not modern in the least but had a strange cold breath of the ancient world; they were magnificent creatures, sic oculos, sic ille manus, sic ora fere bat, [such eyes, such hands, such looks]" (Tartt 1992, 32). Detachment enables Morrow to conduct his Greek class in a free and unrestricted fashion. Beyond the designation that Hampden is "highly selective" (10), the reader learns that the students in Morrow's class are of a "very limited number" (13) and have "virtually no contact with the rest of the division" (13). As a result, the six Greek students establish an insular community of peers outside the college experience of other undergraduates at the time. As with the closeted world of Oxford in Tom Brown, exclusivity and detachment are the presiding impressions of a liberal education in The Secret History.

Throughout this novel, the study of classical civilisation equates to a deeper understanding of beauty, of art, and of eloquence. Coldness is also important, an attribute akin to Kant's notion of disinterestedness in the understanding of beauty. ${ }^{23}$ Professor Morrow is detached from the students who adore him, vanishing entirely at the end of the novel without explanation. The Secret History hints that a fictional George Orwell, "a keen observer of the glitter of constructed facades" (Tartt 1992, 576-7) once described Morrow as giving off an "impression that he is a man of extraordinary sympathy and warmth. But what you call his 'Asiatic serenity' is, I think, a mask for great coldness" (577). By the end of the novel, Papen is aware of this "distinct coldness of manner" (573) of his teacher. When his students come to him with their confession, Papen describes regarding Morrow "for the first time as he really was: not the benign old sage, the indulgent and protective good-parent of my dreams, but ambiguous, a moral neutral, whose beguiling trappings concealed a being

\footnotetext{
${ }^{23}$ See Kant's Critique of Judgement (1790) $\$ 541$.
} 
watchful, capricious and heartless" (574). Morrow is represented through the eyes of a student who idolises him; Papen admits that, "it has always been hard for me to talk about Julian without romanticising him" (575). Although Morrow is surpassed, it is because ultimately, "there comes a time when we have to transcend our teachers" (586) and the reader is reminded that although "remote and often cruel" his students "loved him, in spite of, because" (578) of his detachment. The Secret History is a novel in which the reader is permitted to enter, along with Papen, into a closed-off world. The atmosphere is something typically inaccessible to most would-be students from the narrator's blue-collar background.

Similarly to Hughes' novel, the fictional campus resembles Tartt's alma mater: Bennington College, Vermont. ${ }^{24}$ The actual present-day mission statement of the college reads: "to place students at the helm of their own education; to guide them in the direction of their greatest potential; and to enlarge, deepen, and transform their lives" (Bennington College n.d.). In the novel, Papen describes his college as: "co-ed. Progressive. Specializing in the liberal arts. Highly selective". This Gradgrindian description of the college is enhanced by the following quotation from the fictional Hampden marketing brochure:

Hampden, in providing a well-rounded course of study in the Humanities, seeks not only to give students a rigorous background in the chosen field but insight into all the disciplines of Western art, civilization, and thought. In doing so, we hope to provide the individual not only with facts, but with the raw material of wisdom. (Tartt 1992, 10)

This description of a liberal education is reminiscent of Tom Brown's environment and educational aspirations. Note, however, the decided promise that there will be "facts" in addition to the ambitious attainment of the "raw material of wisdom" (10). In the marketing of Hampden, the need for tangible and measurable forms of knowledge is assured.

As with Tom Brown at Oxford, location plays an important role in The Secret History. The setting is not only necessary to the plot (getting away with murder requires seclusion) but is additionally significant in the presentation of the experience of a liberal education. Vermont State consists of $75 \%$ woodland; in the novel, the density of forested area adds to the sense of being cut-off from the outside world. That the climax of the

${ }^{24}$ Tartt's classmates included novelists Bret Easton Ellis and Jill Eisenstadt. 
novel (the murder of Bunny Corcoran) takes place out in the dense and secluded forest is testament to the isolation of the college. Papen describes the woods as "deathly still", "forbidding", and "green and black and stagnant, dark with the smells of mud and rot" (Tartt 1992, 298). Fellow student Henry Winter's assessment of locale speaks volumes: "Vermont. It's a primitive place. People die violent natural deaths all the time" (190). Violence and nature combine to evoke a sublime quality in the forest that surrounds the campus. Isolation from societal norms is an essential component in the student's descent into Dionysian chaos. The remote locations: the campus itself, Francis' aunt's country estate, the woods, enable the novel to reach frenetic heights.

Although located in an American liberal arts college in Vermont, I argue that Tartt's novel can develop an understanding of representations of the humanities within England. The Secret History makes continual reference to English literary life. The American students imitate English literary circles during the early twentieth century. The reader learns that Morrow was rumoured to have been "a great intellectual in the forties, and a friend to Ezra Pound and T.S. Eliot" (16). Eliot and Pound's émigré status is well known, both denouncing their American roots in favour of the literary life abroad. ${ }^{25}$ In an interview for Vanity Fair, September 1992, James Kaplan documents Tartt's "largish obsession, bordering on the cultic, with T.S. Eliot" (250). Further connections to modernist and interwar literary culture in Britain are found throughout the novel, as Michiko Kakutani observes, the main characters

have less in common with most of their contemporaries than with the bright young things of England immortalized by Waugh and Nancy Mitford: the wilful aesthetes, dedicated to the ideals of beauty and art, who flocked around Harold Acton and Brian Howard at Oxford in the 1920s. $(1992,18)$

The students within the novel are out of time and place, in their academic fascination with the classical world and its rules concerning morality and justice, their aesthetical views of fashion and society, and their day-to-day activities and mannerisms.

\footnotetext{
${ }^{25}$ Francois Pauw notes how the name of "Edmund 'Bunny' Corcoran recalls that of Edmund 'Bunny' Wilson, whose Axel's Castle contains one of the definitive critical appraisals of Eliot” (1994, 142).
} 
Winter, Abernathy, the Macaulay Twins, and Bunny are reflections of the Bright Young Things. Specific examples of this connection are found in the description of the students' dress. For example, Francis Abernathy dresses "like Alfred Douglas" wearing "magnificent neckties; a black greatcoat that billowed behind him as he walked" (Tartt 1992, 18). Charles and Camilla Macaulay are introduced as "long-dead celebrants from some forgotten garden party" (18) and Harry Winter who "wore dark English suits and carried an umbrella (a bizarre sight in Hampden)" (17) presents a vision of Britishness out of place. Before Richard Papenan outsider student-protagonist-becomes more intricately involved and drawn into the lives of these strange students, he makes an astute observation that "they suggested a variety of picturesque and fictive qualities" (17). The characters breathe life into a dead subject, but also, into a dying form of education.

Finally, it is worthwhile to note that The Secret History is located within the context of philosophical and literary culture. Reference, imitation, and allusion are rife: including namedropping T. S. Eliot, echoes of Fitzgerald, to direct citation of Nietzschean morality. ${ }^{26}$ The Secret History relishes the use of literature and, much like Zadie Smith's On Beauty (see Sect. 5.3) is able to capture and realise abstract philosophies in a web of reference and parody. Tartt's novel draws the reader into a world of "knowing", where Morrow, alongside the author, demonstrates a "strange gift of twisting feelings of inferiority into superiority and arrogance" $(1992,576)$. As with the experience of "The Waste Land" (T. S. Eliot 1922), the reader might be unaware of the sources, or the logic of each philosophical mode, but is nonetheless caught up in their effect, in the process of literary experience. As T.S. Eliot outlined in "Ulysses, Order and Myth" this "technique characteristic of heavy mythological, historical, and literary allusions", is used to create a "continuous parallel between contemporaneity and antiquity" (1923, 177). The Secret History attempts to make sense of the modern world through historical and mythical imagery. Tartt explores the physical manifestation of Eliot's ideas in The Secret History as classical lessons come to influence the behaviour and practices of the characters. In The Secret History, the ancient world and its scholarship determines the lives of the students.

\footnotetext{
${ }^{26}$ In regard to Fitzgerald in particular, the narrative tone is similar to The Great Gatsby (1925), but also, in relation to character, see Amory Blaine in This Side of Paradise (1920).
} 


\subsubsection{Assessing the Value of the Humanities in Novels That Engage with Educational Principles from the Past}

Ultimately, the students of Morrow's class learn that the past can be as significant and vibrant as their reality. Unlike the vague notions of university education in Tom Brown at Oxford, Tartt's novel presents an intense experience of studying the humanities. Tom Brown at Oxford is a novel that reinforces the status quo of higher education through nostalgia. The view of education it represents concerns the cultivation of a citizenry, which has the potential to be configured as an antidote to the repeated language of specialisation and skills in contemporary policymaking. Nussbaum's claim that "education [produces] democratic citizenship" $(2010,17)$ is found in Hughes' representation of a liberal education at Oxford in the nineteenth century. However, the lacking interrogation of elitism, implicit nationalism, and gender inequality in Tom Brown at Oxford means that in this sense, it is a problematic tool for articulating the value of the humanities. The following fictional examples in the second and third investigations fail again, but fail better.

The Secret History does not promote nationalism or misogyny, but does little to counter the persistent idea of elitism in education. However, it does offer a critical position against mainstream American College culture and Morrow's handpicked group of Classics students create a scholarly space beyond the reach of external pressures of marketisation. Tartt's novel argues that studying antiquity creates a temporal escape from the encroachment of postmodern scepticism, American capitalism, and wider popular culture. Her frequent use of values from antiquity and twentiethcentury literary theory creates an enticing, albeit dangerous, alternative educational space. The Secret History conveys how scholarship can be animate and captivating.

Tom Brown at Oxford and The Secret History are nostalgic for the power of knowledge in the past. In the final pages of the novel, Papen recalls a section of the Iliad, where Patroklos appears to Achilles in a dream: "Achilles overjoyed at the sight of the apparition - tries to throw his arms around the ghost of his friend, and it vanishes" (Tartt 1992, 627). In a moment, the past is rendered painfully immaterial. Mirroring Achilles, the fate of the students is that, ultimately, their fantasy cannot be maintained. Papen offers a final piece of wisdom from Julian: "the dead appear to us in dreams [...] because that's the only way they can make us see them; what we see is only a projection, beamed from a great distance, light shining at us from 
a dead star" (627 italics original). I argue that Tartt's use of history is much the same; throughout the novel the power of Greek philosophy is, at times, invincible. However, like a dream, the characters cannot avoid the consequences of the present. The illusory experience of the novel must come to an end and the reader, alongside Papen, must face up to the present. The next section explores novels which represent scholarship as a processual experience rather than as a life-philosophy. In doing so, I locate a representation of the humanities that is not, inevitably, a "dead star" (627) and instead presents the process of humanities research as an active experience. Therefore, in moving away from a valuation of the humanities as nostalgia for a bygone era, such literature provides a more vibrant form of resistance.

\subsection{Part IV: Investigation Two: Representing the Processes of Humanities Research}

The above discussion concerning the qualities of a liberal education explored the student-facing relationships to the humanities. This section turns to representations of the process of writing and the embodiment of scholarly knowledge. Middlemarch (G. Eliot 1871) and Possession (Byatt 1990) are both novels that represent the everyday processes of undertaking scholarship: the work of the humanities. They also each explore the relationship between academic knowledge and fiction, despite being published over a century apart. Within these texts, scholarship is revealed to be more than "plodding application, rows of note-books, and small taper of learned theory exploring the tossed ruins of the world" (G. Eliot 1871, 83); both novels explore passion, the power of the imagination, and the real-world implications of intellectual pursuit. In "The Novel Amid Other Discourses" Patricia Waugh argues that the novel "offers a space between the rock of analytical and positivist epistemologies and the (soft) hard place of Nietzschean (and later postmodern scepticism)" (2012, 662). Despite the anti-positivism of humanities research, Waugh argues that novels "have the capacity to build worlds that enable their readers to experience the reality of scholastic, or an enchanted or forgotten sphere of life" (665). As a result, this section explores what Waugh describes as the novel's "unique ways of knowing" (662). The space of the novel-form makes room for an enquiry into value that has hitherto been missing from the contemporary valuation of the humanities. 
In this investigation, I consider how the novel offers "a morally committed enquiry [which is] impossible within academic disciplinary regimes of pure and disinterested research" (Waugh 2012,662). Although Eliot and Byatt reveal different dimensions of a life spent in the humanities, when read together, they establish an articulation of the practices of scholarly study and an applied example of novels as tools for knowing.

\subsubsection{Middlemarch and the Pursuit of The Key to All Mythologies}

Virginia Woolf famously pronounced Middlemarch to be "one of the few English novels written for grown-up people" (1919). Karen Chase suggests the novel "withstands the pressures of time, circumstance and personality" $(2006,3)$. Robert McCrum describes it as a "cathedral of words [that] stands today as perhaps the greatest of the great Victorian fictions" (2014). ${ }^{27}$ As well as being an exemplary Victorian novel in general, Middlemarch is recognised as a "supreme academic fiction" (Showalter $2005,7)$. Although the novel precedes the modern canon of academic fiction, it nonetheless renders vividly the scholarly work of the humanities. The Reverend Edward Casaubon, a scholar of antiquity, represents a model of scholarship that is arcane and, by Eliot's harsh presentation, devoid of any value. As a clergyman based outside of the university, or any other formal educational environment, Casaubon is, at first glance, a somewhat unconventional choice for a humanities scholar. However, the link between the clergy and scholarly learning reflects the realities of nineteenth-century higher learning. ${ }^{28}$ The predominant portrait is a deeply unflattering one. Casaubon's life is a moral lesson for the humanities: the danger of "liv[ing] too much with the dead" (G. Eliot 1871, 18). In the history of the fictional humanities scholar Casaubon stands as perhaps "the most haunting spectre of the academic as grim pedagogue, the scholar as the spirit of all that is sterile, cold and dark" (Showalter 2005,

${ }^{27}$ This high praise is reflected in my personal impression of Middlemarch. It is a book which continually asserts that you will never truly finish reading it.

${ }^{28}$ John Henry Cardinal Newman is another renowned example, with his ecclesiastic lectures on the higher education being published as The Idea of the University (1852). Newman was instrumental in the founding the Catholic University of Ireland, which today is University College Dublin. In addition, the relationship between scholarly work and religion was commonly represented in fiction throughout the mid-late Victorian period, such as Mr Francis Arabin in Barchester Towers (1857) or Richard Phillotson in Jude the Obscure (1894). 
7). Quite unlike the allure of the cool disinterestedness of Professor Morrow in The Secret History, Casaubon is a ghost capable of provoking disquietude in most humanities scholars.

However, above and beyond being a dark totem of academic conceit, I argue that the representation of such an unlikeable character opens up a discussion about the potential of the novel form to contribute to the advancement of knowledge. Middlemarch as a text, as a way of knowing, acts to defy Casaubon's valuation and uses of learning. Elizabeth Hale argues that in Middlemarch, Eliot "advocates for the novel as a key medium of serious, intelligent and valuable thought, in part through the representation of destructive modes of thinking" $(2010,242)$. It is clear that Casaubon is a representation of this destructive mode. His unfinished magnum opus, The Key to All Mythologies, is an endless, pointless, seemingly Sisyphean task. It epitomises Eliot's central criticism of scholarly work in Middlemarch: that it is self-absorbed and without real-world application. Colin Kidd describes how "The Key to All Mythologies has become a byword for the mind-numbingly recondite and is typically thought of as a scene of arid and misguided pedantry" $(2016,29)$. But unlike the fruitlessness of Casaubon's work, the form of the novel itself offers an educative experience with an aspiration towards value beyond Eliot's desire to construct it.

Against scholarly inertia, Eliot configures Middlemarch as a representative space for value, connecting universal qualities of humanistic research and practical processes through the weaving narrative structure of one "particular web" (1871, 140). In "Sickly Scholars and Healthy Novels", Hale argues that Middlemarch demonstrates:

the value of an integrated intellectual approach to life: by revealing the sterile qualities of minds that exist only to feed on their own inner resources, and of scholarship that exists only to destroy, rather than to create. [The] novel form, $[\ldots]$ shows the richness of nineteenth-century fiction's engagement with intellectual debate, and the power of the novel in nourishing the life of the mind. $(2010,242-43)$

An "integrated intellectual approach" is what the novel aspires towards, and Casaubon is configured as a counterpoint to the linear thrust of the narrative. Stasis dominates the representation of Casaubon; his very soul is "swampy" (G. Eliot 1871, 279). Hale observes that swamplands "are unhealthily liminal: too damp to be fertile ground, too dry to be a river, 
pool or ocean" $(2010,223)$. In Middlemarch water represents the experiences of knowledge. For example, excitement about greater understanding runs through Dorothea Brooke as an "electric stream" (27) when her uncle presents her with pamphlets to read. In naïve admiration of Casaubon's scholarly knowledge, she remarks: "what a lake compared with my little pool!" (25). Other academic figures in the novel are associated with fish. "Carp", "Pike", and "Tench" (281) are introduced as rival scholars, sharing names with freshwater fish which all inhabit still and deep waters. ${ }^{29}$ The image of staleness recurrently describes Casaubon; his home at Lowick has "an air of autumnal decline" (74) wherein "fatigue was apt to hang over the intervals of studious labour" (63). As Casaubon's role in the novel concludes, Eliot describes The Key to All Mythologies as a work whose "significance $[\ldots]$ is to vanish as the waters which come and go where no man has need of them" (422). A useless body of water is the resting place of the "futile scholarship" (423) of The Key to All Mythologies.

The very first mention of water in Middlemarch occurs in the prelude, in reference to a "brown pond" (4). Again, the imagery of a restricted body of water resonates with Casaubon's scholarly stagnation. Eliot offers this tragic image of scholarly limitation: "here and there a cygnet is reared uneasily among the ducklings in the brown pond, and never finds the living stream in fellowship with its own oary-footed kind" (4). This cygnet surely is Dorothea, one of the many St. Theresas who has "found for themselves no epic life" (3), and are destined to live a life of "unhistoric acts" and "rest in unvisited tombs" (830). Eliot's reference to the "living stream" (4), beyond, gestures to something that Middlemarch as a knowing novel attempts to capture. It is true that this noble attempt is expressed as striving rather than as attainment. Just as Dorothea (and the cygnet) never reach the "living stream" (4), so the narrator struggles towards, but perhaps never quite reaches, capturing "the roar which lies on the other side of silence" (194).

For Casaubon, the process of scholarship is stagnant and unproductive. This representation serves the humanities scholar a warning; Eliot presents an unrelenting portrait of a life spent "toiling in the morass of authorship without seeing nearer to the goal" (85) resulting in the "lifeless embalmment of knowledge" (196). The Key to All Mythologies will never be published and the knowledge is out of touch with contemporary work on the Continent. Will Ladislaw remarks cruelly to Dorothea that Casaubon's

\footnotetext{
${ }^{29}$ For an extensive reading of fish imagery in Middlemarch see Kidd (2016, 176-99).
} 
book is outmoded as "new discoveries are constantly making new points of view" (222) and makes significant omissions because of "the necessity of knowing German" (221) in order to keep abreast of the contemporary developments in the field. Irrelevance is made manifest in both Casaubon's physical body and the spaces he occupies in the novel. He has a spectral persona: "[Casaubon's] mind is something like a ghost of an ancient, wandering around the world and trying mentally to construct it as it used to be, in spite of ruin and confusing changes" (18). The association between scholarship and death is recurrent. Even in the opening romance of the novel, when Dorothea regards Casaubon as an oracle, he is associated with static and dark spaces. Her admiration is described in the lexicon of museology: "everything he said seemed like a specimen from a mine, or the inscription on the door of a museum which might open on the treasures of past ages" (32-3). The recurrent links to Casaubon and antiquity shift from these arguably positive enshrinements to more negative representations throughout the novel. He admits, "I live too much with the dead" (18) in the opening pages of the novel. As Casaubon approaches death, Dorothea imagines the task of sorting through The Key to All Mythologies:

she pictured to herself the days, and months, and years which she must spend sorting what might be called shattered mummies, fragments of a tradition which was itself a mosaic wrought from crushed ruins - sorting them as food for a theory which was already withered in the birth like an elfin child. (478)

The images of a ruined museum vividly evoke the withdrawal of Dorothea's admiration for Casaubon and his knowledge. All that remains are "shattered mummies" and "crushed ruins" (478), in contrast to the former "attractively labyrinthine" (24) qualities of his mind. The principal problem with Casaubon is his connection to the past as opposed to the present. How are we to construct a value for the humanities scholar in this narrative of Dorothea's naïve hope turning to bitter disillusionment? David Daiches asserts that "it is not lack of theological credulity, but lack of intellectual and imaginative power above all, certain defects of character, which render Casaubon's research abortive" $(1963,18)$. The image of the "elfin child" (G. Eliot 1871, 478) is perhaps the darkest metaphor for the inaction of scholarly enquiry. 
In the Times Literary Supplement, 16 February 1974, Richard Ellmann describes how Eliot uses the figure of Casaubon to represent bad scholarship. He writes: "Casaubonism is the entombing of the senses in the mind's cellarage" (166). In the novel, James Chettam explicitly wonders "does he [Casaubon] even have a heart?" (69), and Mrs Cadwallader's response, "not the melting sort" (69), represents the rigidity of mind that limits Casaubon in both love and learning. It is Chettam's question that is answered again, ironically, in Casaubon's death. His heart is the very organ that fails him; as the site of his major attack the library becomes his deathbed and his sedentary scholarly life causes the "fatty degeneration of the heart" (423). A careful reader observes that when Tertius Lydgate informs Casaubon that the disease is fatal, the doctor feels "a little amusement mingling with his pity" (423). Here, Eliot also is laughing at the pathetic plight as Casaubon faces in realising "the incompleteness of labours, which have extended through all [the] best years" (422) of his life.

Despite this damning presentation, I argue that hope remains for the humanities in Middlemarch in the potential of a more imaginative scholar who is able to embrace the continual progression of a field of humanistic knowledge. Most importantly, unlike The Key to All Mythologies, Middlemarch reaches publication. In this sense, Eliot succeeds in passing her literary knowledge and articulation of the values of a liberal education into the world. Hale argues that Eliot's novel "vastly supersede the abilities of Casaubon" $(2010,242)$. The formal quality of Middlemarch, such as the scope and scale of the narrative, is testament to "the novel's vitality as a new mode of thinking, a new mode of intellectual being" (Hale 2010, 242). Whilst Casaubon's approach of engaging with the humanities is flawed, the desire to know is not dismissed in the same way. A respect for the ability for language to represent life, and the pursuit of an education that is morally virtuous and for the greater good is championed. Dorothea's initial admiration of Casaubon's academic work is revealed to be naïve, and Middlemarch is a novel, in part, about the failure of their marriage and her disappointment in the limited realities of her husband's work. Despite the presentation of an unlikeable scholar, the novel itself inspires an optimistic attitude towards the pursuit of knowledge.

Carol Christ follows this hopeful reading in "The Victorian University and Our Own" suggesting that Eliot is "sceptical of such totalising projects that exclude other perspectives upon phenomena; she is at heart a pluralist. [...] She makes knowledge the instrument of personal transformation, an action upon our mental nature, and the formation of a 
character" $(2008,292)$. Middlemarch's prelude validates Christ's claim, establishing Dorothea as a force of the "indefiniteness" (4) of female potential and of a "passionate [and] ideal nature" (3). In its form and its morality, Middlemarch defends the inherent benefits in pursuing knowledge that is connected to present worldly concerns. Dorothea clearly expresses that "the thing which seemed to her best, she wanted to justify by the completest knowledge; and not to live in a pretended admission of rules which were never acted on. Into this soul-hunger as yet all her youthful passion was poured" (29). In this, Eliot captures the value of an enacted liberal education as a process of living. Herein we might identify hope. Middlemarch supports a liberal education that "educates the intellect, to reason well in all matters, to reach out towards truth, and to grasp it" (Newman 1852, 125-6). Eliot's view aligns with John H. Newman's argument in The Idea of the University, which similarly describes that knowledge as "not merely a means to something beyond it, or the preliminary of certain arts into which it naturally resolves, but an end sufficient to rest in and to pursue for its own sake" $(1852,103)$. In contrast to the stale scholarship of Casaubon, Eliot's striving to know what is thought to be best remains an essential part of representing the work of the humanities.

\subsubsection{Possession and the Processes of Scholarship}

Unlike the oppositional relationship between Eliot's novel and Casaubon's scholarly work, Possession embeds the processes of humanities scholarship within the narrative structure of the book. The text is a palimpsest of diary entries, letters, Victorian artefacts, narrative, dialogue and poetry. Possession inspires through its structural form much in the same way that the process of academic research can be compelling. The plot and structure of the novel are tied up in the "primitive" (Byatt 1990, 258) desire to pursue knowledge. Unlike Casaubon's stagnant scholarship in Middlemarch, Byatt's presentation of scholarly work is "alive" and "urgent" (56). The plot of the novel is driven by academic enquiry and the reader is co-opted as a fellow conspirator alongside the academic protagonists. Reading Possession is to experience of the mental processes of research, and in providing this imaginative understanding Byatt offers a vital representation of the value of the humanities in and of themselves.

The novel follows the actions of a pair of young academics, Maud Bailey and Roland Mitchell, as they follow a paper trail of archival evidence of the 
fictional Victorian poets Randolph Henry Ash and Christabel LaMotte. The novel's opening scene portrays a scholarly scandal in the London Library as the desperate Mitchell steals a secret manuscript, unread for many years, which hints towards a hitherto unknown affair between Ash and LaMotte. As the novel progresses, Bailey (a well-known scholar of LaMotte) and Mitchell (a lesser-known Ash scholar) become obsessed with proving a love affair between the two Victorian writers. In the context of the novel, as in real academic life, such a discovery would equate to scholarly acclaim for the finder. As a result, readers of Possession experience a pastiche of what can be at stake in the research process.

The pacing of Possession is designed to make it a page-turner and the plot, with its reveals and surprises, proves a captivating read. Richard Todd notes that "it is a compelling, addictive read, and the reader submits to it out of passion, along with something one might even term "virtue"" $(1996,44)$. In both form and subject matter, Possession is a novel that invites its reader to take part in the research process, to become immersed in the web of materials, to solve the mystery alongside Bailey and Mitchell. The pleasure of reading Possession is an important part of its advocacy for the value of the humanities. Although the subtitle of the novel is "a Romance", Possession is a detective novel and a work of historical fiction, as well as a romance quest narrative. Moseley argues that Possession is a novel that is "about scholarship - the discovery of documents, the forming of judgments, the revision of critical understanding” $(2007,6)$. Byatt's talent in writing a bestseller about two academics is testament to her skills as an author, but also signifies a genuine public interest in the mysterious world of academia and the archive..$^{30}$ Additionally, Possession provides more crime, sex, and exciting locations than is traditionally expected in academic fiction. The novel begins with theft and ends with the illicit exhumation of a grave; the letters of La Motte contain clear erotic charge; and although the landscape of Possession is hardly exotic, it is Romantic. Forgotten archives, old country houses, the Yorkshire Moors and a gloomy Sussex graveyard establish an intense setting for this narrative.

The entire plot revolves around the actions of living academics and dead poets. The lives of the Victorian poets become enmeshed with lives of the contemporary scholars Bailey and Mitchell. Invented literary

\footnotetext{
${ }^{30}$ Jerome de Groot offers further discussion of academia and the heroic quests in reference to The Da Vinci Code in Consuming History: Historians and Heritage in Contemporary Popular Culture (2009, 49-57).
} 
fragments, articles, diary entries, and poems make Possession an intricate web of history, memoir, and literary art. If the past and the present are in conflict in Middlemarch, in Possession they are intertwined through a passionate affair. Akin to the pluralism of Eliot, Byatt's novel demonstrates an impressive grasp of many different voices. Possession presents the most exciting parts of academic life as relying on a connection to others. At the end of the novel, Bailey would have been unable to solve the mystery without Mitchell's expertise. Unlike the isolation of Casaubon, destined "to work as in a treadmill fruitlessly" (G. Eliot 1871, 479), Mitchell and Bailey follow their paper trail on a real-life academic quest. This unconventional approach allows the processes of humanities scholarship to be given free rein in the world, let loose from the confines of the campus. Mitchell describes this passion as being "urged on by some violent emotion of curiosity - not greed, curiosity, more fundamental even than sex, the desire for knowledge" (Byatt 1990, 92). To know is perhaps the greatest quest in the romance genre. For example, consider the moment in which Bailey realises her desire to pursue knowledge:

I want to - to - follow the - path. I feel taken over by this. I want to know what happened, and I want it to be me that finds out. I thought you were mad, when you came to Lincoln with your stolen letter. Now I feel the same. It isn't professional greed. It's something more primitive. (1990, 258)

Bailey and Mitchell are active participants, working together and against others in a dynamic process of discovery and knowledge acquisition. In doing so, Possession reminds us how "literary critics make natural detectives" (258).

Bailey, in particular, is a rescued Casaubon, drawn out from the sterile archives into a romantic adventure. The novel permits its protagonists to abandon the guilt of enjoying research and to follow Robert Frost's suggestion of taking the road less travelled. Outside of the formal structures of the university, the novel presents research as a satisfying and exciting ambition, and one "that has made all the difference" (Frost 1916) in providing a positive representation of the humanities. Possession reveals that passion led both Bailey and Mitchell to the humanities in the first instance. Identifying the initial reasons that they became researchers, Bailey explains how Ash's poems "were what stayed alive, when I'd been taught and examined everything else", Maud smiles and agrees "exactly. That's it. What could survive our education" (Byatt 1990, 62). This is not an aspect 
of the humanities that is admitted openly, but is nonetheless a truth that many scholars reflect upon anecdotally. Monica Flegel summarises that Byatt's novel "urge[s] us to leave behind critical readings and embrace reading for enjoyment" $(1998,429)$. The novel valorises a creative approach to scholarship, and in doing so, an affective dimension of humanities scholarship is given life within the space of the novel.

The bodies of the academics themselves come to represent the pursuit of passion and romance. In chasing down the secret affair of the Victorians, Mitchell and Bailey fall into their own academic romance. As the pair consummate their love, the narrative makes a connection between the present and the past: "very slowly and with infinite gentle delays and delicate diversions and variations of indirect assault, Roland finally, to use an outdated phrase, entered and took possession of all of her white coolness" $(1990,550)$. Even in this moment of physical intimacy, Byatt's narrative continues to generate a relationship between the present and the past that animates humanistic scholarship. When Mitchell sleeps next to Bailey, he is "a dark comma against her pale elegant phrase" (44): a most embodied representation of the humanities.

\subsubsection{Assessing the Value of the Humanities in Novels That Explore the Process of Writing and Research}

Above, I have suggested that the experience of reading particular fictional work offers a reader an experiential understanding of humanities research. Here, I consider how the novel form itself contributes to an understanding of values in the humanities. In "Literature and Life", Giles Deleuze outlines the following perspective on the relationship between fiction and reality:

literature [...] exists only when it discovers beneath apparent persons the power of an impersonal - which is not a generality but a singularity at the highest point: a man, a woman, a beast, a stomach, a child [...] it is not the first two persons that function as the condition for literary enunciation; literature begins only when a third person is born that strips us of the power to say "I". Of course, literary characters are perfectly individuated and are neither vague nor general, but all their individual traits elevate them to a vision that carries them off in an indefinite, like a becoming that is too powerful for them: Ahab and the vision of Moby Dick. $(1997,227)$ 
Deleuze's statement is applicable to Dorothea in Middlemarch, one of the "many Theresas" (G. Eliot 1871, 3) whose lives were not attributed any value until Eliot assumed the responsibility of representing such endeavours. Throughout Middlemarch the narrative explores scalar shifting, from representative to general imagery. This ability for fiction to represent the individual experience as a universal one is valuable in articulating the value of the humanities. In "The Natural History of German Life" Eliot argues that fictional representations offer "the raw material of moral sentiment" which marks a sharp relief from the languages of "generalizations and statistics" $(1883,145)$. Eliot recognises that "language is an instrument which scarcely anything short of genius can wield with definiteness and certainty" (164) since it provides "anything but a rational state" (164). The irrationalism and imagination of fiction is able to articulate, although not always definitively, the muddled matter of "moral sentiment". Thinking further along these lines, Eliot imagines the uselessness of a language that:

has no uncertainty $[\ldots]$ - a patent deodorized and non-resonant language, which effects the purpose of communication as perfectly and rapidly as algebraic signs. Your language may be a perfect medium of expression to science, but will never express life, which is a great deal more than science. $(1883,164-5)$

Academic fictions should be recognised for their ability to animate the values of the humanities with a great deal more life than economic policy could ever afford.

Possession is a novel that equally addresses the vitality of knowing. The intertextuality and interconnection characterises the lives of the academic characters, and the nineteenth-century poets, but ultimately, it also represents the plural-character of the humanities. In a vocation that is so often comprised of isolated and individuated scholars, Byatt's presents a vision of academic life that is generated between Mitchell and Bailey, in interaction with historical characters and other academic characters, in a method that is "neither vague nor general" (Deleuze 1997, 227). The vitality of literary research is what carries Bailey and Mitchell to their eventual discovery in Possession. The representation of the value of the humanities is located in the practice of academic research; "possession" is a heightened state of being, as opposed to an object to owned. 


\subsection{Part V: Investigation Three: Pressures of ECONOMICS IN EDUCATION}

This section moves on to a discussion of the values of scholarship against economic pressure. In Imagining the Academy, Edgerton discusses how her position as a professor provides "a disturbing standpoint from which to observe some of the worst trends in social and cultural change, as well as the best" $(2005,1)$. This section explores how the novel performs a similar function. As this chapter comes to its final literary investigation, the selected texts are drawn back into contact with economic rationalism, the market, and an interrogation of the dominant discourse that shapes the valuation of the humanities within higher education. For this task, I focus on Thomas Hardy's Jude the Obscure (1894), Frank Parkin's The Mind and Body Shop (1986) and Zadie Smith's On Beauty (2005). Each provides a different representation of the limiting nature of the market in the valuation of higher education.

\subsubsection{Jude the Obscure and Barriers to Education}

Hardy's final novel highlights those who are excluded from the luxury of liberal education. Jude the Obscure is in many ways an anti-academic fiction, since the protagonist never achieves entry into the scholarly community at Christminster. As with Middlemarch, Hardy's novel is epic in scale. To discuss access to higher education in Jude the Obscure is to concentrate on a small fragment of a vast portrait. In doing so, I focus only on the first two parts of the novel "At Marygreen" and "At Christminster" with some reference to Jude's later life in the sixth part "At Christminster Again". Albert Guerard suggests that scholars might best tackle the enormity of the scope of Jude the Obscure by dividing it into a "multiplicity of separate and detachable problems" $(1949,32)$. Following this schema, I address one of the seven problems that Guerard identifies, that is, "the socio-economic problems of education opportunity for the poor and of class deracination" (32). The following analysis delivers what the above discussion of Tom Brown at Oxford omits, including the representation of the difficulties of access to higher education.

The images of higher education presented in Jude the Obscure are economic hardship and class prejudice. In Tom Brown at Oxford the closest reference to economic struggle is represented in a character named Hardy, co-incidentally. Hardy is a "servitor", a position that fellow undergraduate 
Drysdale cruelly describes as being "something in the upper-servant line [who] does the don's dirty work, and gets their broken victuals, and I believe he pays no college fees" (Hughes 1959, 292). Hughes' Hardy works within the college in order to receive tuition and elaborates upon his social standing in a self-contained confessional chapter "Hardy's History" (311-323). In this section, the reader finds that "with the exception of one of the tutors, and one man who was a freshman with me, [Hardy] does not know a man in college except as a mere speaking acquaintance" (1859, 318). John Reed documents that "it remained a belief of the Victorians that important class contacts were to be established through public school associations" (1974, 63). It is evident that Hardy's economic class renders him a social pariah even though he is able to gain access to an Oxford education. In contrast, Thomas Hardy's eponymous character Jude Fawley is destined to remain on the outside of the educational institution. Jude nurtures his dream to go to the university town of Christminster and find a home amongst scholarly men. Although he succeeds in making the physical pilgrimage to the city he remains socially and economically excluded and is unable to participate in the intellectual life around him.

Jude exhibits a fascination with the town of Christminster from an early age. He seeks out high vantage points to catch a glimpse of the "city of light" (Hardy 1895, 25) on the horizon. The fictional Christminster is closely modelled on Oxford which, as discussed above in the context of Tom Brown at Oxford, allows Hardy to draw upon a rich contextual and symbolic history. Christminster assumes an intellectual and religious aura in Jude's mind. Philip Hobsbaum observes that the protagonist "wanders about Oxford, but is somehow excluded from it. His longing, however, is almost an aesthetic one - for cloisters and quadrangles, for processions decked out in academic regalia" $(2006,23-24)$. In time, even the physical architecture of Oxford is a restrictive barrier to education: "only a wall but what a wall!” (Hardy 1895, 102). Despite suffering both social and physical exclusion, Jude remains enraptured: "Beautiful city! So venerable, so lovely, so unravaged by the fierce intellectual life of our century, so serene! $[\ldots]$ her ineffable charm keeps ever calling us to the true goal of all of us, to the ideal, to perfection" (96-97). Jude echoes the sentiments of Oxford as a site of humanistic learning that is at a remove from the pressures of policy, able to approach "the ideal" of a liberal education.

Other townspeople in Marygreen proffer negative attitudes about the city. In a salient episode, an unnamed cart driver warns Jude "you'd have 
to get your head screwed on t'other way before you could read what they read there" (23). The cart driver describes how "em lives on a lofty level; there's no gainsaying it, though I myself med not think much of 'em" and explains how "[high] be they in their minds - noble-minded men enough, no doubt -some on 'em - able to earn hundreds by thinking aloud" (23). He warns Jude that somebody belonging to his socio-economic background would be unsuited to life in Christminster. The inclusion of the carter's perspective is unusual in a discussion about higher education but offers valuable insight into how academia can be perceived in the wider world. This is a far more cynical vision than Charles Dickens presents in Great Expectations (1860-1), for example, when the blacksmith, Joe Gargery, maintains an abstract belief in the transformative power of education despite struggling to spell his own name.

Within Jude the Obscure, Jude's cousin and lover Sue Brideshead encapsulates Jude's difficult economic circumstances by stating that, "you are one of the very men Christminster was intended for when the colleges were founded; a man with a passion for learning, but no money, or opportunities or friends" (181). In a vivid image of exclusion, Sue observes how Jude is metaphorically "elbowed off the pavement by millionaire's sons" (181). Hardy's position is unambiguous: access to education is unfair and in need of redress. Noddings describes how Jude the Obscure "caused a storm of outrage among some of the highly educated - some of it aroused by the pessimism of the novel, some surely by its depiction of the snobbery and intellectual isolation of academe" $(2013,78)$. This criticism drove many nineteenth-century scholars to defend what they saw as the relative openness of the academy. Since Jude has no access to the professors themselves, it is the physical structures of the university that become caricatured: "some were pompous; some had put on the look of family vaults above ground; something barbaric loomed in the masonries of all" (Hardy $1895,99)$. In his manual labouring as a stonemason, Jude builds the very structures of the institutions that deny him access. Bill Jones argues that Jude "works on the fabric of the college buildings, work without which the buildings could not survive, and yet there is no chance for him to gain the inside of these walls" $(2009,25)$. Hardy presents material work and immaterial education as completely distinct but in a relationship that reinforces their separation. Despite this memorable image of educational injustice, it is significant to notice that throughout the novel Jude continually aspires towards education and remains hopeful for the future. In the penultimate chapter, Jude reflects on the lack of opportunities afforded 
to him: "I felt as if I could do one thing if I had the opportunity. I could accumulate ideas, and impart them to others. I wonder if the Founders had such as I in their minds - a fellow good for nothing else but that particular thing?" (Hardy 1895, 478). That Jude fails to gain acceptance into Christminster is tragic. He dies with sounds of celebration from the honorary graduation ceremony at Cardinal College floating through his window, a jarring image that challenges readers to consider the exclusion of the working classes from higher education and the lives of those who struggle in obscurity.

The Victorian era was a period of transformation in higher education; Carol Christ provides a concise history of change in "The Victorian University and Our Own":

In 1836, the King ended the monopoly that Cambridge and Oxford had over the awarding of university degrees by granting a royal charter to the University of London, which had begun offering university-level instruction in 1826. Owens College, Manchester, admitted its first class in 1851; in 1851, John Henry Newman went to Ireland to establish a Roman Catholic university in Dublin. The University of Bristol opened in 1876; Mason College of Science, which became the University of Birmingham, in 1880. University colleges were also founded in Hull, Southampton, Reading, Nottingham, Exeter, and Leicester. Between 1848 and 1871, the first women's colleges were founded at Oxford and at Cambridge. $(2008,287)$

Despite improved access to universities being heralded throughout the 1890s, the vision portrayed in Jude the Obscure, first published in 1894, demonstrates that these events had not alleviated the socio-economic limitations on university attendance. In 1892, the University of Oxford established the Standing Committee of the Delegacy of Local Examinations, offering a more diverse and accessible adult education programme for the first time. A significant improvement was the foundation of Ruskin College in 1899. This independent educational institution, deliberately located in Oxford, was designed for working-class men to attend university and "educate themselves efficiently at nominal cost" (Edwards 1902, 71). In the 'Postscript' of the 1912 edition, Hardy notes how he "was informed that some readers thought these episodes an attack on venerable institutions, and that when Ruskin College was subsequently founded it should have been called the College of Jude the Obscure" (xv). However, the exclusion of Jude is not exclusively an "attack" (xv) that is devoid of hope. 
Jude gestures "there are schemes afoot for making University less exclusive, and extending its influence, I don't know much about it. And it is too late, too late for me! Ah - and for how many worthier ones before me" (Hardy 1895, 479). Education in Jude the Obscure remains an unresolved problem for the lower and middle classes. Nevertheless, Hardy's attempt to engage with educational reform through fiction is testament to the ways in which literature has the potential to alter public opinion, stimulate debate, and instigate social change.

The final two examples in this chapter engage more directly with the present context of neoliberalism within higher education. Frank Parkin's The Mind and Body Shop (1986) and Zadie Smith's On Beauty (2005) offer two approaches to addressing the current state of higher education in England through fiction. Each provides a very different entry point into the debate concerning economics and the humanities. On Beauty unabashedly extolls the present-day potential of a liberal education in higher education while Parkin presents a near-future dystopia in which higher education has become commercialised beyond recognition and repair. Where Parkin is brash, Smith is ambiguous. Although each author adopts and explores different approaches, they both offer productive defences of the value of the humanities under economic pressure.

\subsubsection{Frank Parkin's The Mind and Body Shop: Everything for Sale}

The Mind and Body Shop presents a speculative vision of higher education in a near-future, dystopian England. However, the future that Parkin forecasted in 1987 represents a world very close to reality today. Although The Mind and Body Shop is presented as hyperbole, many elements of the novel are recognisable in the commercial spirit of contemporary higher education under neoliberalism in England. As a result, Parkin's critique of the "glass and metal" $(1987,191)$ university offers readers a satirical portrait of a "competitive" (read neoliberal) university. ${ }^{31}$ The novel extends academic frustrations to their most hysterical lengths: a class on Spinoza is taught in a Jacuzzi to make it more popular, the titular Mind and Body

\footnotetext{
${ }^{31}$ The language of competition is pervasive in many university marketing campaigns. For example the Twitter biography from University College Cork (@UCCResearch) reads as follows: "University College Cork (UCC) is an internationally competitive, research-led University".
} 
Shop refers to a literal store in which the Philosophy department is forced to sell the subject to passers-by on the street. Parkin's novel makes manifest Stefan Collini's vision of "scholars becoming "door-to-door salesmen for vulgarized versions of their increasingly market-oriented products" (Collini 2009, 18). In The Mind and Body Shop the commodification of education has taken its literal extreme by being located in a retail unit. Parkin uses absurdity as a tool to critique the more incremental changes occurring within higher education during the 1980s. The Mind and Body Shop differs from conventional campus fiction, since it ridicules the economic context of higher education as opposed to a specific faculty. The satire is aimed at the level of the institutional system, as opposed to an individual academic life.

Parkin's character of the Vice Chancellor is the most haunting embodiment of neoliberal higher education. He is the mouthpiece of much of the commercial language in the novel, seeking to manage the university in the same style as his previous post at "the East Midlands division of Consolidated Tractor Fuels" (Parkin 1987, 39). ${ }^{32}$ According to the Vice Chancellor "anything can be sold if it's properly presented" and each subject is merchandise: "a commodity, just like any other" (12). Political philosopher Michael Sandel observes how "today, almost everything is up for sale" $(2013,3)$. Parkin's vision of the corporate university opens up a debate about how far an education institution might be marketised before it loses sight of its purpose and simply becomes another business. In The Mind and Body Shop the Vice Chancellor states that the function of the modern university is "to give customer satisfaction" (1987, 38) and reminds the academic staff that "the days of the ivory tower were over long ago" (14). Resembling the fictional Vice Chancellor of the University of Poppleton from Laurie Taylor's weekly cartoon in the Times Higher Education (see Fig. 4.2), the Vice Chancellor in Parkin's novel is presented as a ruthless businessman with no regard for knowledge beyond the potentials of economic profit or institutional prestige.

The counterpoint to the damning corporate portrait of the Vice Chancellor in The Mind and Body Shop is the philosophy professor, Douglas Hambro, who represents the last bastion of academic integrity in the novel. Hambro believes in the value of philosophy, beyond its

\footnotetext{
${ }^{32}$ However, some academic staff members support the corporate system, such as Hedda Hagstrom who works in Admin I (see 173) and the unnamed Professor of Fisheries Science, (see 206).
} 

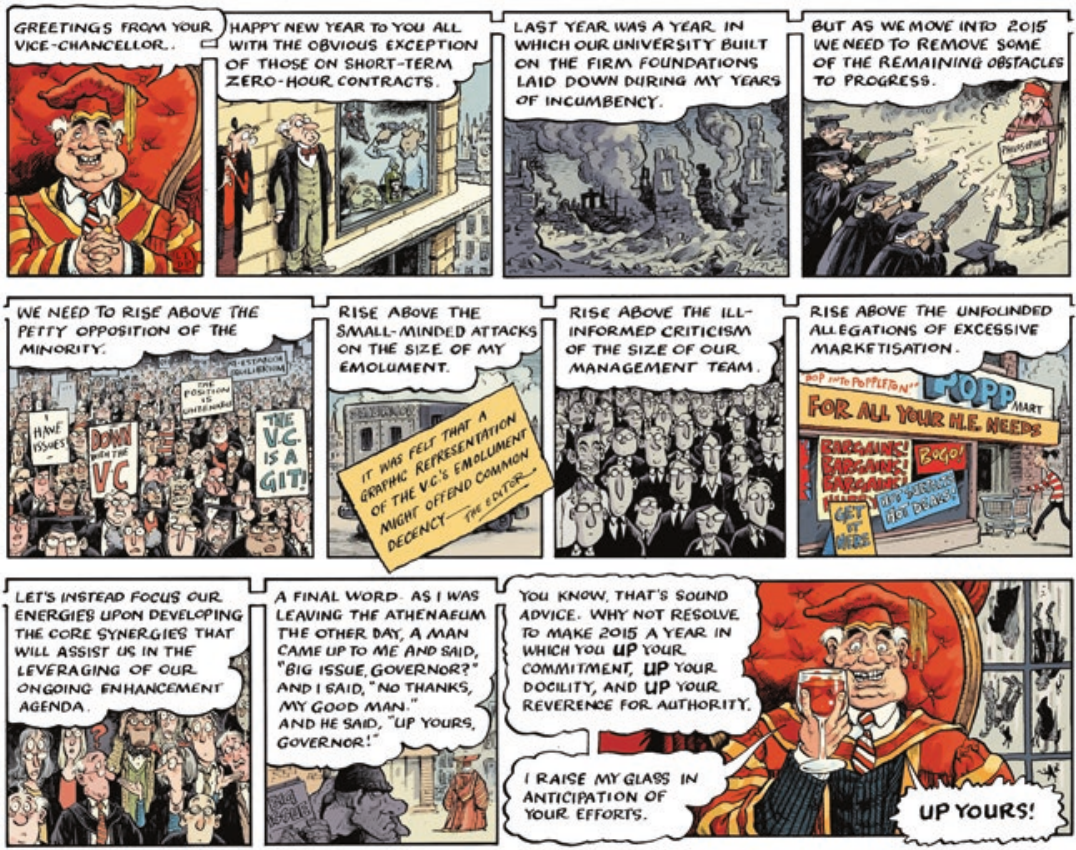

Fig. 4.2 Laurie Taylor. "Greetings From Your Vice-Chancellor." Times Higher Education, 1 January 2015

economic potential and persistently. Although timid, he argues that “moral philosophy doesn't really lend itself to a purely commercial approach" (12). His attempts prove futile and are tinged with a despondency seen in the "depressive disorientation" (Amsler 2011, 64) in contemporary debates about the crisis of the humanities in higher education in England.

Throughout the novel, Hambro provides a testimony to the economisation of higher education, which is perhaps best captured in the following descriptive passage:

it seemed relatively few years ago that the university was a comfortable backwater of quiet learning and modest scholarship. He could still vaguely remember it as it had been before privatisation. That was the time when students entered the lecture theatres without passing through coin-operated turnstiles. In those days he was not required to preface his seminar on the 
Stoics with a message from the commercial sponsors. Nor was he responsible for sweeping up the room afterwards. After all these years he could still not get accustomed to adding the suffix Inc. to the name of the university, nor to renting his office on a monthly tenancy. He could not even look forward to the prospect of his imminent retirement now that the pension had been abolished. (Parkin 1987, 13)

The scenes detailed by Hambro are simultaneously absurd and conceivable. The novel was reviewed in the New York Times, 16 August 1987, as "an uncomfortable madcap vision" (Hawes 1987). However, the horror of reading The Mind and Body Shop today, three decades on, it is close to being a truth as well as a fiction; in the present state of neoliberal higher education reading the novel becomes less like a satire, and more akin to a bad day at the office. Zero-hours contracts with hot-desking is the equivalent of the "monthly tenancy" that Hambro describes. Corporate sponsorships seep into universities through many unlikely avenues and it is now not unusual to find students receiving an advertisement at the beginning of an academic lecture. ${ }^{33}$

In The Mind and Body Shop, the effects of market rationale inherent in contemporary higher education are imagined at their radical conclusion. Jonathan Hull observes that Parkin's novel offers a scenario in which "professors are no longer valued for their knowledge or teaching skill but for their flair for raising money and tailoring research to fit corporate sponsors" (1987, 114). Today, funding bodies and large corporations looking to finance universities often focus investment in hard science subjects (STEM) or business-based courses, where the results of study are direct, short-term, and product-based. The idea of impact dominates discussions of value in higher education and it is difficult to imagine how subjects in the humanities can substantiate their worth in these empirical terms. The idea of a philosophy department running a "Lunchtime Special: Schopenhauer in the Shopping Hour" (Parkin 1987, 122) is farcical, as is the presentation of a "matinée performance of Kierkegaard-a-GoGo" (160). Parkin's novel foregrounds the alternative values that are in decline. The failure of Philosophy to become a marketable product is indicative of the unsuitability of evaluating education through market rationality.

\footnotetext{
${ }^{33}$ Recent personal experience at the University of Exeter includes the sponsorship of stair risers within the Student's Guild for PwC; KPMG as the title sponsor of the University of Exeter Athletic Union; to my horror, I once found a classroom in which cans of the energy drink Red Bull had been stuck to the underside of the tables as a promotion.
} 
In What Are Universities For? Collini asserts that "one of the main sources of confusion these days is the misleading analogy between a university and a commercial company" $(2012,134)$ and argues that "if the only justification for spending money is that it contributes to making money" (137) we are clearly missing out on many important human activities. The desperate marketing of the subject of philosophy in The Mind and Body Shop raises the question of the value of morality, which physically cannot be sold. The novel concludes with a haunting query: "wasn't it Merleau-Ponty who said that whatever would happen to philosophy today would happen to the world tomorrow?" (Parkin 1987, 220). Whilst the attribution of this quotation is dubious, this enquiry lies at the heart of how The Mind and Body Shop works to disrupt and trouble the market logic of higher education. ${ }^{34}$ With this in mind, Lodge's conception that "the university is a kind of microcosm of society at large" $(1986,169)$ assumes further significance. For Parkin, the marketisation of philosophy is representative of the spread of neoliberalism, no matter how ill-suited, into all sectors of public life.

Despite its all-too-accurate speculations, The Mind and Body Shop has long been out-of-print and is rarely cited in contemporary critical discourse. Regardless of its lack of popularity or critical acclaim, the novel offers an illuminating example of how the effects of economisation of education can be starkly rendered in fiction. To read The Mind and Body Shop is to straddle a world close to our present situation, and one that imagines the future of education institutions that scholars must work together to prevent. Parkin's novel tackles the uncomfortable changes head-on and encompasses the pressures of economisation. As a professor of sociology, as opposed to a creative writer-in-residence, Parkin "displays a rare and generally undervalued talent for writing satirical accounts of academic practice" (Chalfen 2003, 377). The Mind and Body Shop presents a stark dystopian vision of the future that we may or may not already be living in. Unlike the expression of the value of the humanities through its literary nuance (as in Possession and On Beauty), Parkin's novel tackles the context of neoliberalism directly by placing a price on the practice of philosophy.

\footnotetext{
${ }^{34}$ There is no record of Merleau-Ponty ever making such a claim; however, his Humanism and Terror (1969) does suggest that Marxism is the only political model to avoid meaningless development. Merleau-Ponty states that "to denounce [Marxism] is to dig the grave of Reason in history. After that there can be no more dreams or adventures" (153). Parkin was a scholar and critic of Marxism, therefore, Parkin's misquotation is likely deliberate and satirical.
} 


\subsubsection{The Future of a Liberal Education in Zadie Smith's On Beauty}

Unlike Parkin's little-read academic fiction, On Beauty is a popular academic novel. It was shortlisted for the Man Booker Prize (2005), won the Orange Prize for Fiction (2006), and made the New York Times bestseller list. Additionally, given its contemporaneity, On Beauty most readily speaks to the present moment in higher education. It offers an intensive literary examination of the crisis in the humanities. Smith offers a realistic vision of a humanities department, which conforms to many of the expectations of traditional campus fiction. For example, while The Secret History offered glimpses of contemporary education, the focus on antiquity and mysticism obscures a realistic representation of university life today. Reading Smith's novel in direct contrast to Byatt's, Tartt's, and Parkin's, the plot is calm and the tone is sincere. Alexander Dick and Christina Lupton argue that On Beauty presents "a strong sense that the humanities today are in a state of crisis: the values of equality and relativism assumed in the principles of liberal education have been outpaced [...] by the competitive forces of the market" $(2013,115)$. Although the signs of economisation are less obvious in Smith's novel than in The Mind and Body Shop, they have significant repercussions even while they simmer beneath the surface.

Reading On Beauty as a document of the state of contemporary higher education in England, one might object that the majority of the action in the novel is located on the wrong continent. However, I argue that the representation of the humanities in On Beauty is transatlantic and, therefore, draws particular attention to the close relationship between British and American higher education institutions. Numerous academic novels detail the connections among transatlantic academic circles, most famously in Malcolm Bradbury's Stepping Westward (1965) and David Lodge's Changing Places(1975). It is also important to note that many of the same debates concerning the value of the humanities in England are presently being loudly stated in the US. For example, Henry Giroux details the "growing corporatization and privatization at all levels of schooling" (2000) on the other side of the Atlantic. Whilst On Beauty is predominately set in America, both central characters as well as their author are British. Monty Kipps is an Anglicised Trinidadian (the latter identity being one he seeks to distance himself from), living 
in Wellington, located on the outskirts of Boston. Howard Belsey is a British immigrant living in the US and is keen to leave his working-class roots behind.

Monty and Howard, the two central protagonists in the novel, are binary opposites much like the Vice Chancellor and the Professor Hambro in The Mind and Body Shop. A sense of competition and pressure of success within an academic hierarchy motivates their actions throughout the novel. Smith opens On Beauty with an epigraph from renowned humanist Harold J. Blackham that simply states: "we refuse to be each other" (2005, 2 ). Monty and Howard are near-perfect antagonists. The intellectual battleground between the two Art Historians is well worn, since "for fifteen years the two men had been moving in similar circles; passing through the same universities, contributing to the same journals, sometimes sharing a stage - but never an opinion - during panel discussions" $(2005,29)$. The tension between these two colleagues is accentuated by Monty's recent publication on Rembrandt, much to Howard's frustration as he had been working on a Rembrandt biography for many years. Their books are also counterparts: Howard's Against Rembrandt provides an intricate antihumanist reading, whilst Monty's "hugely popular (and populist) brick [is] designed to sit heavily atop the New York Times bestseller list for half a year" (29). Monty is a charismatic and confident "cultural conservative" (115). His knighthood and influential media-type friends evidence his social standing. Howard, the "radical art theorist" (115) is a paranoid, bumbling, highly self-critical liberal. Literary critic Susan Alice Fischer demonstrates how "the conflict between Howard and Monty, though professional and political, is shaped by a multi-layered personal history as well as by a different ideological interpretation of history" $(2013,87)$ : the basis of their conflict lies in fundamental differences in their moral, political, and philosophical beliefs. Such agonism speaks to the discussion in Chap. 3 concerning debates between Snow and Leavis, and Arnold and Huxley.

Rather than exploring tensions between disciplines, Smith's novel explores conflict within them. The metaphor at the heart of On Beauty is that Howard and Monty personify the oppositional views of the culture wars. In doing so, Smith references a convention within the genre of the 
academic novel. ${ }^{35}$ Smith's portrayal of these broad political divisions as being embodied in two professors' hatred for one another fast-tracks a reader's interest in the affairs of the academy without getting weighed down by academic jargon or anecdotal departmental in-fighting. Instead, the characters represent a universal debate, which had shaped politics inside and outside the university setting for decades, an indeed, in different forms since Antiquity. The only commonality that Howard and Monty share is that neither expresses any doubt in the value of academic study. Smith's academics are in disagreement about how Art History should be researched and taught but both fervently believe that it is of value. Smith's novel thus promotes the benefits of the humanities regardless of the specific school of thought that engagement in education relies upon. On Beauty is a novel that extolls the power of aesthetics, the experiences of life and learning, and is a treatise on beauty itself, perhaps the most unquantifiable and least-outcome driven of all areas of study.

In the above discussion of academic fiction, many of the characters identified as pivotal in understanding the value of the humanities are male. This is a trend within campus fiction, with female characters often sidelined as romantic interests, nuisances, or the wives of professors. ${ }^{36}$ The character of Zora Belsey presents a relief from this male-dominated conversation. The inclusion of a female perspective on the crisis, albeit from a somewhat secondary character in On Beauty, is worthy of further consideration. Zora is Howard Belsey's daughter and an undergraduate student at the University of Wellington. She represents an optimistic future for the disciplines untarnished by the departmental bitterness of Howard or Monty. As Frank Rich argues: "by not taking sides in the Belsey-versusKipps debate, [Smith] wants to lift us to the higher view not dreamt of in their philosophies. It's too late for burnt-out cases like Howard and Monty, who are both far too jaded and cynical to see past the culture wars to the beauty of culture itself" (2005). Zora believes in the potential of the university, and of intellectual activity more widely, as a force for social good. Despite growing up in an academic household, Zora "had the strangest ideas about academics — she found it extraordinary that they

\footnotetext{
${ }^{35}$ The prevalence of the culture wars is reflected as a popular topic in numerous academic novels, most notably in Alison Lurie's The War Between the Tates (1974) and John L'Heureux's The Handmaid of Desire (1996).

${ }^{36}$ See further discussion in Deegan, D. (1951); Carter, I. (1990) 159-66; Rađenović, M. (2016).
} 
should be capable of gossip or venal thoughts. She was hopelessly naïve about them" (Smith 2005, 111).

I argue that Smith uses Zora as a tool for communicating the aspirations of the university anew. She gives voice to the transformative power of a liberal education in the twenty-first century. Like John Stuart Mill stated in his famous address at St Andrews, Zora is committed to understanding "what beauty is [and to] desire to realize it in [her] own life will keep before [her]self a type of perfect beauty in human character, to light [her] attempt at self-culture" (Mill 1867, 255). In alignment with the aspirations of liberal thinkers in the Victorian age, who sought to uphold certain educational values during its expansion in England, Zora cherishes the same ideals, even when surrounded by the market-driven and competitive culture of contemporary American higher education. Zora's idealisation of knowledge, in an age "after Foucault" (Smith 2005, 219) stands as a representative image for the future, and the continued support for the value of the humanities despite the controversy of the culture wars. She acts as an intermediary between Howard and Monty and represents an attempt to reconcile (or abandon) the fissures left in the academy after the culture wars. The name 'Zora' has an alliterative link to Zadie herself, and her naïve optimism in the future of the university echoes Smith's personal reflections. In interview, Smith is quick to defend the value of higher education: "to me, a university is one of the most precious of human institutions; that's why when they fall short of their own ideals, you feel so cheated" (2014). Following the publication of On Beauty Smith reflected: "I wanted to be an academic and planned to be one, and then I started writing White Teeth - ten years of my life vanished into novels. I certainly think of it as the road less travelled, a road I would have liked to go down" (2014). Smith has taught as a creative writing professor at New York University for over eight years (2010-present), which-in a very real sense-represents the power of fiction in defending the values of higher education. Her articulation of the necessity of a liberal education is evident in the actions of her fictional characters, but also in her public interviews and work as a writer within a university setting. ${ }^{37}$

\footnotetext{
${ }^{37}$ Smith has also served as a writer in residence at Institute of Contemporary Arts, London, fellow at the Radcliffe Institute for Advanced Study at Harvard, and has taught fiction at Columbia University School for the Arts.
} 


\subsection{Conclusion}

This chapter has focused on the articulation of the value of the humanities within academic fiction. Investigative and interpretative readings of academic fiction provide a way to question what it means to undertake humanities scholarship from a position outside economically-focused debates regarding specific government policy. Markets tell us that such stories have no value, however, the lived experience portrayed in literature tells us otherwise. Fictional representation provides an alternative mode of valuation as opposed to economic indicators of success. Reading academic fiction and further exploring the possibility that the telling itself can be a discursive tool for developing a robust response to the current changes within higher education from a humanities perspective. In The Space of Literature, Blanchot observes that "literary works seem to leave comprehension behind and yet seem never to reach it, so that it must be said of them that they are always understood too much and always too little" $(1982,239)$. The novel negotiates a place between the particular (i.e. the life of a single academic) and the general (i.e. intellectual values and ethical responsibilities).

I argue that the novel opens up an alternative space for considering value, between the humanities and the policymaker. It is this "search for and analysis of values" (Gardner 1978, 19) that has been examined in the fictional examples of this chapter, which act as testimonials of the ability to articulate value beyond the monochromatic language of the marketplace. In this way, despite cliché and satiric representations, the novels offer productive representations with which to better understand our current situation. The three investigations explored above, provide different dimensions of articulating the value of an education in the humanities, each of which has strengths and limitations as forms of representation. The first discussion, that considered the nostalgic liberal education model portrayed in Tom Brown at Oxford and The Secret History, does little to tackle elitism but offers insight into the experience of an education that is driven by aspirations unrelated to metrics and quantified knowledge. The second investigation, on Middlemarch and Possession, explored a more embodied representation of the value of the humanities in processes of research and connection to others. The "particular web" (G. Eliot 1871, 
140) of Middlemarch created a fictional space to articulate the potential of literature to convey humanistic meaning, while the quest narrative of Possession captured a sense of the excitement inherent in intellectual pursuit. The third investigation addressed novels that directly negotiate economic values within an educational setting. Jude the Obscure continues to demonstrate the power of imaginative work to represent and challenge systemic societal injustices. Parkin and Smith offer diverse responses to the corporate university that can be used to highlight the forgotten narratives of value that neoliberalism seeks to render unintelligible. The Mind and Body Shop defamiliarises the structures neoliberalism that we have become numb to, reminding us that its end result-Philosophy in a Jacuzzi-is nonsense. On Beauty offers an optimistic recognition of the enduring appeal of the core values of aesthetic scholarship.

Academic fiction is a productive site wherein contemporary debates can be explored beyond the limits of white papers with a language that allows the values of higher education enough space to thrive. The importance of this methodological approach is particularly evident when contrasted with the depressing terminology of business-speak which Chap. 5 turns to address. Literary representation offers a break from the myopic position that articulating worth in terms of economic value is the only way to preserve the humanities in the neoliberal university.

\section{BIBLIOGRAPHY}

Allen, Nick. 2015. Students Asked to Sit Final University Exam in Nude With Naked Professor. The Telegraph, May 11, Accessed 17 Mar 2017, via www. telegraph.co.uk/news/worldnews/northamerica/usa/11598556/Studentsasked-to-sit-final-university-exam-in-nude-with-naked-professor.html Amis, Kingsley. 1954. Lucky Jim. London: Victor Gollancz.

- 1973. Real and Made Up People. Times Literary Supplement, July 27, 847

. 2004. Memoirs. London: Vintage.

Amsler, Sarah. 2011. Beyond All Reason: Spaces for Hope in the Struggle for England's Universities. Representations 116: 62-89.

Aristophanes. 423 BC. The Clouds. Reprint 1959. Oxford: Clarendon Press. Arnold, Matthew. 1853. Scholar Gipsy. The Poems of Matthew Arnold, 1840-1867.

[1909]. Oxford: Oxford University Press. 
1865. The Function of Criticism at the Present Time. Reprinted in Culture and Anarchy, and Other Writings, ed. Stefan Collini, 2001, 26-51. Cambridge: Cambridge University Press.

- 1866. Thyrsis: A Monody, to Commemorate the Author's Friend, Arthur Hugh Clough, Who Died at Florence, 1861. Macmillan's Magazine. Vol. XIII (78): 449-454.

Asquith, Mark. 2017. Reading the Novels of John Williams: A Flaw of Light. Lanham, MD: Rowman and Littlefield.

Barnes, Julian. 2013. Stoner: the Must-Read Novel of 2013. The Guardian, December 13, Accessed 12 May 2014, via www.theguardian.com/books/ 2013/dec/13/stoner-john-williams-julian-barnes

Beerbohm, Max. 1911. Zuleika Dobson, or, an Oxford Love Story. London: William Heinemann.

Bennington College. 2015. Bennington College. "History and Vision" Bennington College Website, May 1, Accessed 2 May 2016, via www.bennington.edu/ About/history.aspx

Bigsby, Christopher. 2013. Stoner: a Classic Tale of a 'Small' Academic Life. Times Higher Education, September 12, Accessed 15 May 2016, via www.timeshighereducation.com/features/stoner-a-classic-tale-of-a-small-academic-life/ 2007119.article

Blanchot, Maurice. 1982. The Space of Literature. Trans. Ann Smock, Originally Published in France as L'Espace littéraire [1955]. Lincoln: University of Nebraska Press.

Bolaño, Roberto. 2009. 2666. Trans. Natasha Wimmer. New York: Picador.

Bradbury, Malcolm. 1965. Stepping Westward. London: Secker and Warburg.

- 1975. The History Man. London: Harvill Secker.

Brooks, Cleanth, and Robert Penn Warren. 1959. Understanding Fiction. New York: Appleton-Century-Crofts.

Byatt, A.S. 1990. Possession: A Romance. New York: Random House.

Caram, Richard G. 1980. The Secular Priests: A Study of the College Professor as Hero in Selected American Fiction, 1955-1977. PhD thesis. St. Louis University.

Carter, Ian. 1990. Ancient Cultures of Conceit: British University Fiction in the Post-War Years. London: Routledge.

Cather, Willa. 1925. The Professor's House. New York: Alfred A. Knopf.

CBS Local. 2015. UCSD Professor on Naked Final Exam: 'It's A Standard Canvas For Performance Art, Body Art'. CBS Local Online. May 11, Accessed 6 June 2017, via www.losangeles.cbslocal.com/2015/05/11/ucsd-professor-onnaked-final-exam-its-a-standard-canvas-for-performance-art/.

Chabon, Michael. 1995. Wonder Boys. New York: Villard Books. 
Chalfen, Richard. 2003. Hollywood Makes Anthropology: The Case of Krippendorf's Tribe. Visual Anthropology 16: 375-391.

Chase, Karen. 2006. Introduction. In Middlemarch in the 21st Century, ed. Karen Chase, 3-14. Oxford: Oxford University Press.

Christ, Carol. 2008. The Victorian University and Our Own. Journal of Victorian Culture 13 (2): 287-293.

City \& Guilds Centre for Skills Development. 2008. Skills Development: Attitudes and Perceptions. City and Guilds Centre for Skills Development. Accessed 24 June 2016, via www.skillsdevelopment.org/pdf/Skills-development-attitudesand-perceptions-research-summary-report.pdf

CNN. 2015. Students Forced to Take Final Naked. CNN Online. May 11, Accessed 6 June 2017, via www.edition.cnn.com/videos/us/2015/05/10/pkg-studentsforced-to-take-final-naked.kgtv?sr=tw051115nakedfinals10pVODLink

Coetzee, John M. 1999. Disgrace. London: Harvill Secker.

Collini, Stefan. 2009. Impact on Humanities: Researchers Must Take a Stand Now or Be Judged and Rewarded as Salesmen. Times Literary Supplement, November $13,18-19$.

. 2012. What Are Universities for? London: Penguin.

Confederation of British Industry (CBI). 2012. Learning to Grow: What Employers Need From Education and Skills. CBI. Accessed 24 June 2016, via www.cbi.org.uk/media/1514978/cbi_education_and_skills_survey_2012.pdf

Connor, Steven. 2001. The English Novel in History 1950 - Present. New York: Routledge.

Dahlgreen, Will. 2015. Bookish Britain: Literary Jobs are the Most Desirable. YouGov, February 15, Accessed 18 Feb 2015, via www.yougov.co.uk/ news/2015/02/15/bookish-britain-academic-jobs-are-most-desired/

De Groot, Jerome. 2009. Consuming History: Historians and Heritage in Contemporary Popular Culture. London: Routledge.

Deegan, Dorothy Yost. 1951. The Stereotype of the Single Woman in American Novels. New York: King's Crown Press.

Deleuze, Giles. 1997. Life and Literature. Critical Inquiry 23 (2): 225-230.

Delillo, Don. 1985. White Noise. New York: Viking Press.

Deresiewicz, William. 2007. Love on Campus. The American Scholar, June 1, Accessed 20 July 2016, via theamericanscholar.org/love-on-campus/\#

Dexter, Colin. 1987-2000. Inspector Morse, Performance by John Thaw, Oxford: ITV.

Dick, Alexander, and Christina Lupton. 2013. On Lecturing and Being Beautiful: Zadie Smith, Elaine Scarry and the Liberal Aesthetic. English Studies in Canada 39 (2-3): 115-137. 
Dominiquez, Ricardo. n.d. Visual Arts 104A: Performing for the Self. Course syllabus. University of California, San Diego. Accessed 23 Mar 2017, via www. thing.net/ rdom/ucsd/self.html

Dougill, John. 1998. Oxford in English Literature: The Making, and Undoing of 'The English Athens'. Ann Arbor: The University of Michigan Press.

Eagleton, Terry. 1988. The Silences of David Lodge. New Left Review 172: 93-102. Edgerton, Susan, and Paul Farber. 2005. Imaging the Academy: Higher Education and Popular Culture. Oxford: RoutledgeFalmer.

Edwards, Joseph. 1902. Ruskin Hall, Oxford: The People's University. Glasgow: Joseph Edwards.

Eliot, George. 1871-72. Middlemarch, a Study of Provincial Life. Edited with an Introduction and Notes by Rosemary Ashton 1994. London: Penguin.

- 1883. The Natural History of German Life. In The Essays of George Eliot, ed. Nathan Sheppard, 141-177. New York: Funk and Wagnalls.

Eliot, T.S. 1922. The Waste Land. London: Criterion.

- 1945. Ulysses, Order and Myth. In Selected Prose of T. S. Eliot, ed. T.S. Eliot, 177-179. New York: Farror, Straus, Giroux.

Ellmann, Richard. 1973. Dorothea's Husbands: Some Biographical Speculations. Times Literary Supplement, February 16, 165-168.

- 1982. James Joyce. Oxford: Oxford University Press.

Eve, Martin Paul. 2016. Literature Against Criticism: University English and Contemporary Fiction in Conflict. Cambridge: Open Book Publishers.

Everett, Percival. 2001. Erasure. Lebanon, NH: University Press of New England. Felski, Rita. 2015. The Limits of Critique. Chicago: University of Chicago Press.

Fischer, Susan Alice. 2013. 'Temporal Layers': Personal and Political History in Zadie Smith's On Beauty. In Reading Zadie Smith: The First Decade and Beyond, edited by Philip Tew, 83-96. London: Bloomsbury.

Fitzgerald, F. Scott. 1920. This Side of Paradise. New York: Scribner. 1925. The Great Gatsby. New York: Scribner.

Flegel, Monica. 1998. Enchanted Readings and Fairy Tale Endings in A. S. Byatt's Possession. English Studies in Canada 24: 413-430.

Foden, Giles. 2011. Sufficient Event: Preparations for a Ghost Story. Malcolm Bradbury's Website. December 2, Accessed 18 Jan 2015, via www.malcolmbradbury.com/essay_uea_and_creative_writing.html

Foucault, Michel. 1975. Discipline and Punish: The Birth of the Prison. Trans. Alan Sheridan [1995]. New York: Vintage.

Frayn, Michael. 1989. The Trick of It. New York: Viking Press.

Frost, Robert. 1920. The Road Not Taken. In Mountain Interval. New York: Henry Holt and Company.

Gagnier, Regenia. 1991. Subjectivities: A History of Self-Representation in Britain, 1832-1920. Oxford: Oxford University Press.

Gardner, John. 1978. On Moral Fiction. New York: Basic. 
Gaskell, Elizabeth. 1855. North and South. London: Chapman and Hall.

Gathorne-Hardy, Jonathan. 1977. The Public School Phenomenon. London: Hodder and Stoughton.

Giroux, Henry A. 2000. Cultural Politics and the Crisis of the University. Culture Machine. 2. Accessed 12 June 2016, via www.culturemachine.net/index.php/ $\mathrm{cm} /$ article/view/309/294

Gissing, George. 1893. The Odd Women. London: Lawrence and Bullen.

Godwin, Gail. 1974. The Odd Woman. New York: Alfred A. Knopf.

Guerard, Albert. 1949. Thomas Hardy. Cambridge, MA: Harvard University Press.

Guillory, John. 1993. Cultural Capital: The Problem of Literary Canon Formation. Chicago: The University of Chicago Press.

Hale, Elizabeth. 2010. Sickly Scholars and Healthy Novels: The Classical Scholar in Victorian Fiction. International Journal of the Classical Tradition 17 (2): 219-243.

Hall, Stuart. 1992. The West and the Rest: Discourse and Power. In Formations of Modernity, ed. Stuart Hall and Bram Gieben, 185-227. Cambridge: Polity Press.

Hampson, Sarah. 2013. Stoner: How the Story of a Failure Became an All-Out Publishing Success. The Globe and Mail, December 7, Accessed 12 May 2015, via www.theglobeandmail.com/arts/books-and-media/stoner-how-the-storyof-a-failure-became-an-all-out-publishing-success /articlel5803253/

Hardy, Thomas. 1895. Jude the Obscure. 1994. London: Penguin.

Hargreaves, Tracy. 2001. The Secret History: A Readers' Guide. London: Continuum Contemporaries.

Harrison, Brian. 1995. Shorter Notices. The English Historical Review CX (439): 1327-1328.

Hawes, Elizabeth. 1987. Free Will Is Our Only Choice. New York Times, August 16, Accessed 3 Mar 2016, via www.nytimes.com/1987/08/16/books/freewill-is-our-only-choice.html

Hensher, Philip. 2011. King of the Badgers. London: Fourth Estate.

Hobsbaum, Philip. 2006. University Life in English Fiction. In The Academic Novel: New and Classic Essays, ed. Merritt Moseley, 20-32. Chester: University of Chester.

Houellebecq, Michel. 2015. Submission. Heinemann.

Hughes, Thomas. 1857. Tom Brown's Schooldays. Reprinted in Tom Brown's Schooldays and Tom Brown at Oxford, 1997. Ware: Wordsworth Classics.

Hughes, Thomas. 1859. Tom Brown at Oxford. Reprinted in Tom Brown's Schooldays and Tom Brown at Oxford, 1997. Ware: Wordsworth Classics.

Hull, Laurence. 1987. Book Review. Library Journal 12 (13): 144.

James, Henry. 1875. Roderick Hudson. 1879. London: Macmillan and Co. Jarrell, Randall. 1954. Pictures from an Institution. Chicago: Phoenix Fiction. Jones, Bill. 2009. Only a Wall - but What a Wall!. Adults Learning 21 (7): 24-26. 
Joyce, James. 1916. A Portrait of the Artist as a Young Man. New York: B. W. Huebsch.

Kakutani, Michiko. 1992. Books of the Times; Students Indulging In Course of Destruction. The New York Times. September 4, Accessed 12 Mar 2015, via www.nytimes.com/1992/09/04/books/books-of-the-times-students-indulgingin-course-of-destruction.html

Kant, Immanuel. 1790. Critique of Judgement. Ed. Nicholas Walker and Trans. James Creed Meredith (2007). Oxford: Oxford University Press.

Kaplan, J. 1992. Smart Tartt. Vanity Fair, September, 248, 250-251, 276-278.

Kidd, Colin. 2016. The World of Mr Casaubon Britain's Wars of Mythography, 1700-1870. Cambridge: Cambridge University Press.

Kreider, Tim. 2013. The Greatest American Novel You've Never Heard Of. The New Yorker, October 20, Accessed 12 Jan 2018, via www.newyorker.com/ books/page-turner/the-greatest-american-novel-youve-never-heard-of

L'Heureux, John. 1996. The Handmaid of Desire. London: Soho Press.

Larkin, Philip. 1946. Jill. London: The Fortune Press.

Lodge, David. 1975. Changing Places. London: Harvill Secker.

- 1984. Small World. Reprint 2012. London: Random House.

- 1986. Write On: Occasional Essays 1965-1985. London: Secker and Warburg.

- 1988. Nice Work. London: Secker and Warburg.

Lubenow, William. 2010. Liberal Intellectuals and Public Culture in Modern Britain, 1815-1914. Woodbridge: Boydell \& Brewer.

Lurie, Alison. 1974. The War Between the Tates. New York: Random House.

McCarthy, Mary. 1952. The Groves of the Academe. New York: Harcourt.

McCrum, Robert. 2014. The 100 Best Novels: No 21 - Middlemarch by George Eliot (1871-2). The Guardian, February 10, Accessed 27 Feb 2014, via www.theguardian.com/books/2014/feb/10/100-best-novels-middlemarchgeorge-eliot

Melvin, Barbara. 1996. Failures in Classical and Modern Morality: Echoes of Euripides in The Secret History. Journal of Evolutionary Psychology 17: 53-63.

Merleau-Ponty, Maurice. 1969. Humanism and Terror. Trans. John O'Neill. Boston: Beacon Press.

Mill, John Stuart. 1867. Inaugural Address Delivered to the University of St Andrews. In Collected Works of John Stuart Mill, Vol. 21, ed. John M. Robson. Toronto: University of Toronto Press.

Moseley, Merritt. 2007. Introduction. In The Academic Novel: New and Classic Essays. Chester: Chester University Press.

Mourby, Adrian. 1996. The Question's Academic. Times Educational Supplement, August 16, Accessed 22 Mar 2016, via www.tes.co.uk/article. aspx? storycode $=37407$ 
Mourshed, Mona, et al. 2012. Education to Employment: Designing a System That Works. McKinsey Center for Government. Accessed 25 June 2016, via www.mckinseyonsociety.com/downloads/reports/Education/Education-toEmployment_FINAL.pdf

Nabokov, Vladimir. 1957. Pnin. London: Heinemann.

Newman, John. 1852. Discourse 5. Knowledge its Own End." in The Idea of a University John Henry Cardinal Newman. London: Longmans, Green, and Co.. Accessed 2 Apr 2015, via www.newmanreader.org/works/idea/discourse 5 .html

Nicholls, David. 2003. Starter for Ten. London: Hodder Paperbacks.

Noddings, Nel. 2013. Renewing the Spirit of the Liberal Arts. The Journal of General Education 62 (2-3): 77-82.

Nussbaum, Martha. 1990. Love's Knowledge: Essays on Philosophy and Literature. New York: Oxford University Press.

- 2010. Not for Profit: Why Democracy Needs the Humanities. London: Princeton University Press.

Parini, Jay. 2000. The Fictional Campus: Sex, Power, and Despair. The Chronicle of Higher Education 47 (4): 12-13.

Parkin, Frank. 1987. The Mind and Body Shop. London: Fontana Paperbacks.

Pauw, Francois. 1994. If on a Winter's Night a Reveller: The Classical Intertext in Donna Tartt's the Secret History. Akroterion 39 (3-4): 141-163.

Proctor, Mortimer. 1957. The English University Novel. Berkeley, CA: University of California.

Pullman, Phillip. 1995, 1997, 2000. His Dark Material Trilogy. Northern Lights, 1995. The Subtle Knife, 1997. The Amber Spyglass, 2000. New York: Scholastic.

Rađenović, Milica. 2016. Class and Gender - The Representation of Women in Kingsley Amis's Lucky Jim. Gender Studies 15 (1): 183-195.

Reed, John R. 1974. The Public Schools in Victorian Literature. NineteenthCentury Fiction 29 (1): 58-76.

Reynolds, Pauline. 2014. Executive Summary. Representing "U": Popular Culture, Media and Higher Education 40 (4): vii-ix.

Rich, Frank. 2014. Zadie Smith's Culture Warriors. The New York Times, September 18, 2005, Accessed 12 Dec 2014, via www.nytimes. com/2005/09/18/books/review/zadie-smiths-culture-warriors.html.

Rossen, Janice. 1993. The University in Modern Fiction: When Power Is Academic. Basingstoke: Palgrave Macmillan.

Roth, Philip. 2000. The Human Stain. Boston: Houghton Mifflin Harcourt.

Sandel, Michael. 2013. What Money Can't Buy: The Moral Limits of Markets. London: Penguin.

Schneider, Ana-Karina. 2016. The Romance of Reading (in) Academic Fiction. American, British and Canadian Studies 26 (1): 3-13.

Sharpe, Tom. 1974. Porterhouse Blue. London: Secker and Warburg. 
Shklovsky, Victor. 1917. Art as Technique. In Russian Formalist Criticism: Four Essays. Trans. and Ed. Lee T. Lemon and Marion Reis [1965]. Nebraska: University of Nebraska Press, 5-22.

Showalter, Elaine. 2005. Faculty Towers: The Academic Novel and Its Discontents. Oxford: Oxford University Press.

Smith, Zadie. 2005. On Beauty. London: Penguin.

- 2014. A Conversation with Zadie Smith. Penguin Book Clubs. May 6, Accessed 22 Sep 2016, via www.penguin.com/read/book-clubs/ on-beauty/9780143037743.

Snow, Charles Percy. 1951. The Masters. London: Macmillan.

Spurling, Hilary. 1999. RLF Fellowship Scheme. rlf.org.uk, March, Accessed 3 Aug 2015, via www.rlf.org.uk/education/rlf-fellowshipscheme/.

Stoner, John. 1965. Stoner. New York: Viking Press.

Tartt, Donna. 1992. The Secret History. London: Penguin.

Taylor, Laurie. 2015. Greetings From Your Vice Chancellor. Times Higher Education, January 1, Accessed 16 June 2017, via www.timeshighereducation.com/comment/the-poppletonian/greetings-from-your-vice-chancellor/2017671 article

Terzian, Sevan G., and Patrick A. Ryan. 2015. American Education in Popular Media. Basingstoke: Palgrave Macmillan.

Tierney, William G. 2002. Interpreting Academic Identities: Reality and Fiction on Campus. The Journal of Higher Education 73 (1): 161-172.

Todd, Richard. 1996. Consuming Fictions: The Booker Prize and Fiction in Britain Today. London: Bloomsbury.

Trollope, Anthony. 1857. Barchester Towers. London: Longman, Brown, Green, Longmans, \& Roberts.

- 1870. On English Prose Fiction as a Rational Amusement. In Four Lectures, ed. L. Morris Parrish. [1938]. London: Constable.

- 1883. An Autobiography Vol. 1. [2014] Cambridge: Cambridge University Press. Accessed via https://doi.org/10.1017/CBO9781107280090

@UCCResearch. n.d. University College Cork (UCC) is an internationally competitive, research-led University. Twitter. Accessed 12 May 2017, via www.twitter.com/UCCResearch.

UKCES. 2014. Forging futures: Building Higher Level Skills through University and Employer Collaboration. UK Commission for Employment and Skills (UKCES), September 22, Accessed 26 June 2016, via www.universitiesuk.ac. uk/highereducation/Documents/2014/ForgingFutures.pdf

Walkerdine, Valerie. 1990. Schoolgirl Fictions. London: Verso.

Watson, George. 1978. Fictions of Academe: Dons and Realities. Encounter 51: 42-45. 
Waugh, Patricia. 2012. The Novel Amid Other Discourses. In The Cambridge History of the English Novel, ed. Robert Caserio and Clement Hawes, 661-676. Cambridge: Cambridge University Press.

Williams, Jeffrey J. 2012a. Deconstructing Academe. The Chronicle of Higher Education, 58, 25, February 24, Accessed 12 Oct 2017, via chronicle.com/ article/An-Emerging-Field-Deconstructs/130791/

- 2012b. The Rise of the Academic Novel. American Literary History 24 (3): 561-589.

Womack, Kenneth. 2002. Postwar Academic Fiction: Satire, Ethics, Community. Basingstoke: Palgrave Macmillan.

Woolf, Virginia. 1919. George Eliot. Times Literary Supplement. November $20,657-8$.

Open Access This chapter is licensed under the terms of the Creative Commons Attribution 4.0 International License (http://creativecommons.org/licenses/ by $/ 4.0 /$ ), which permits use, sharing, adaptation, distribution and reproduction in any medium or format, as long as you give appropriate credit to the original author(s) and the source, provide a link to the Creative Commons licence and indicate if changes were made.

The images or other third party material in this chapter are included in the chapter's Creative Commons licence, unless indicated otherwise in a credit line to the material. If material is not included in the chapter's Creative Commons licence and your intended use is not permitted by statutory regulation or exceeds the permitted use, you will need to obtain permission directly from the copyright holder.

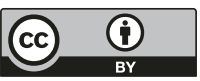

